\title{
Montmorillonite-anchored magnetite nanocomposite for recovery of ammonium from stormwater and its reuse in adsorption of $\mathrm{Sc}^{3+}$
}

\author{
Jianzhi Song ${ }^{1} \cdot$ Varsha Srivastava $^{1} \cdot$ Tomas Kohout $^{2} \cdot$ Mika Sillanpää $^{3,4,5,6,7,8} \cdot$ Tuomo Sainio $^{1}$ (1)
}

Received: 7 June 2021 / Accepted: 28 August 2021 / Published online: 15 September 2021

(c) The Author(s) 2021

\begin{abstract}
The treatment of stormwater to remove and recover nutrients has received increasing interest. The objective of this study was to develop a novel adsorbent that is easy to handle, has good adsorption capacity, and is economical to use. A novel nanocomposite of montmorillonite (MT)-anchored magnetite $\left(\mathrm{Fe}_{3} \mathrm{O}_{4}\right)$ was synthesised by co-precipitation as an adsorbent for ammonium. The $\mathrm{MT} / \mathrm{Fe}_{3} \mathrm{O}_{4}$ nanocomposite had pore sizes $(3-13 \mathrm{~nm})$ in the range of narrow mesopores. The dispersion of the anchored $\mathrm{Fe}_{3} \mathrm{O}_{4}$ was confirmed by transmission electron microscopy, scanning electron microscopy, and X-ray photoelectron spectroscopy (XPS). The nanocomposite exhibited higher affinity towards ammonium than the original MT. The Langmuir isotherm model was found to be the most suitable model to explain the ammonium adsorption behaviour of the nanocomposite. The maximum adsorption capacity for ammonium was $10.48 \mathrm{mg} / \mathrm{g}$. The adsorption mechanism was a combination of ion exchange and electrostatic interaction. In an authentic stormwater sample, the synthesised adsorbent removed $64.2 \%$ of ammonium and reduced the amount of heavy metal contaminants including $\mathrm{Mn}, \mathrm{Ni}, \mathrm{Cu}$ and $\mathrm{Zn}$. Furthermore, the ammonium loading on $\mathrm{MT} / \mathrm{Fe}_{3} \mathrm{O}_{4}$ during adsorption functionalised the adsorbent surface. Additionally, the spent nanocomposite showed potential for rare earth elements (REEs) adsorption as a secondary application, especially for the selective adsorption of $\mathrm{Sc}^{3+}$. The versatile application of montmorillonite-anchored magnetite nanocomposite makes it a promising adsorbent for water treatment.
\end{abstract}

\section{Graphic abstract}

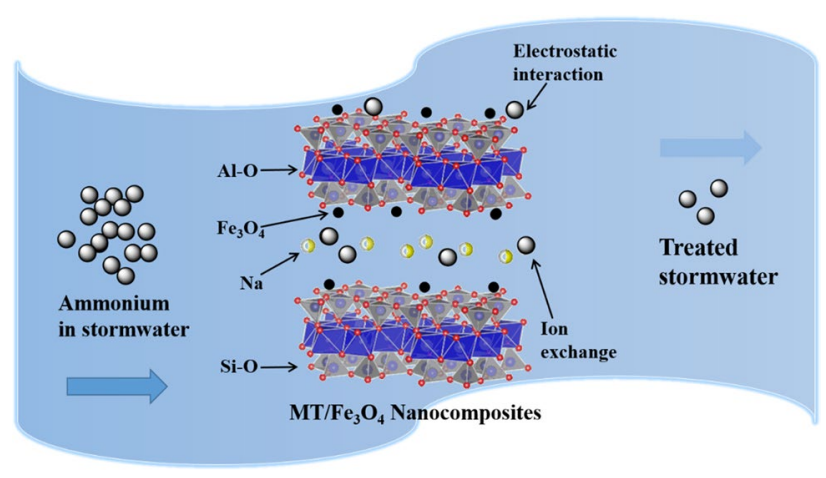

Keywords Stormwater $\cdot$ Montmorillonite $\cdot$ Magnetite $\cdot$ Nanocomposite $\cdot$ Ammonium recovery $\cdot$ REE recovery

Tuomo Sainio

Tuomo.Sainio@lut.fi

Extended author information available on the last page of the article

\section{Introduction}

Urban living is replacing rural land use, increasing the size of impervious areas, reducing the availability of arable land, reducing infiltration and leading to increased surface runoff during storm events. Stormwater mobilises pollutant 
loads (e.g. suspended solids, nutrients, metals, and oxygen-demanding matter) and transports them to receiving water bodies such as rivers, lakes and ponds [1-3]. Nutrients (ammonium and phosphate salts) accumulating in the aquatic environment result in eutrophication and algal blooms, causing the death of aquatic life and degradation of water quality [4]. Ammonium is conventionally removed by biologic processes through nitrification and denitrification. Then, it is finally converted to $\mathrm{N}_{2}$ but with the presence of by-products such as nitrate [5-7]. Moreover, the ammonium content in stormwater varies throughout the year depending on the season and amount of precipitation; this has a negative impact on the biologic treatment. An abiotic process such as adsorption can recover ammonium with low energy consumption as well as deal with the fluctuations in ammonium concentration since adsorbents work efficiently with high concentrations of pollutants as well as trace amounts of contaminants [8-10]. Adsorption is also simple to execute and has low energy requirements [11]. For practical applications, adsorbents should be of low cost with high efficiency and easy recoverability.

Clay minerals are inexpensive, non-toxic natural materials which are widely used in the ceramic, paper, rubber, plastics, cosmetics and medicine industries. Among them is montmorillonite (MT), a one-dimensional crystal of aluminosilicate layers with interlayers of alkali metal and earth cations-typically $\mathrm{Na}^{+}, \mathrm{Ca}^{2+}$, and $\mathrm{Mg}^{2+}$. It is a potential adsorbent owing to its large surface area, stable chemical properties and high cation exchange capacity $[12,13]$. It was reported as an adsorbent with or without modification for the removal of copper $\left(\mathrm{Cu}^{2+}\right)$ [14] and ammonium [15]. The net negative charge on the structure of MT can attract and capture cations, making it a natural candidate for ammonium adsorption.

Recently, many efforts have been made for synthesis of adsorbent material by the incorporation of magnetic nanoparticles. As one of the popular inorganic nanoparticles [16] for wastewater treatment, magnetite $\left(\mathrm{Fe}_{3} \mathrm{O}_{4}\right)$ possesses a high adsorption capacity and a fast adsorption rate. Furthermore, its magnetic feature allows for easy recovery after use [17, 18]. It was recently investigated as an adsorbent for the removal of cadmium $\left(\mathrm{Cd}^{2+}\right)$ [19]. Additionally, an ammonium-pillared $\mathrm{MT} / \mathrm{Fe}_{3} \mathrm{O}_{4}$ nanocomposite was synthesised for caesium $\left(\mathrm{Cs}^{+}\right)$removal from water and soil [20]. Moreover, the semiconductor properties of magnetite provide possible photocatalytic reactions - such as the degradation of organic pollutants-as an extra merit [21-24].

To the best of our knowledge, the use of the nanocomposite form of $\mathrm{MT}$ and $\mathrm{Fe}_{3} \mathrm{O}_{4}$ as adsorbents for ammonium recovery has not been reported. In this study, $\mathrm{MT} / \mathrm{Fe}_{3} \mathrm{O}_{4}$ nanocomposites were synthesised using the co-precipitation method which consumes little power and is environmentally friendly [25] as a low-cost, non-toxic, easy-to-handle adsorbent for ammonium recovery in stormwater treatment. The characterisation of adsorbents-adsorption performance under various dosages, contact time, initial $\mathrm{pH}$ of ammonium solutions, initial concentration of ammonium solutions, kinetics, isotherm models, and stormwater treatment-has been studied thoroughly. Likewise, the ammonium-loaded nanocomposite was applied as an adsorbent for rare earth elements (REEs) recovery, especially for the selective adsorption of $\mathrm{Sc}^{3+}$.

\section{Materials and experimental methods}

\section{Materials}

The montmorillonite (MT, K10 powder) was purchased from Sigma Aldrich. The chemicals used, including iron(II) chloride tetrahydrate $\left(\mathrm{FeCl}_{2} \cdot 4 \mathrm{H}_{2} \mathrm{O}\right)$, iron(III) chloride hexahydrate $\left(\mathrm{FeCl}_{3} \cdot 6 \mathrm{H}_{2} \mathrm{O}\right)$, ammonium chloride $\left(\mathrm{NH}_{4} \mathrm{Cl}\right)$, sodium hydroxide $(\mathrm{NaOH})$ and hydrochloric acid $(\mathrm{HCl})$, were obtained from Sigma Aldrich and used without further purification.

\section{Synthesis of $\mathrm{MT} / \mathrm{Fe}_{3} \mathrm{O}_{4}$ nanocomposites}

The method for the synthesis of $\mathrm{Fe}_{3} \mathrm{O}_{4}$ and $\mathrm{MT} / \mathrm{Fe}_{3} \mathrm{O}_{4}$ nanocomposite was adapted from previous studies with minor modifications [20]. First, $1.8 \mathrm{~g}$ of $\mathrm{FeCl}_{2} \cdot 4 \mathrm{H}_{2} \mathrm{O}$ was dissolved in $150 \mathrm{~mL}$ of deionised water. Then, MT was added to the solution in an ultrasonic bath for $10 \mathrm{~min}$, and the mixture was stirred and heated in an oil bath for $20 \mathrm{~min}$. Next, $2.7 \mathrm{~g}$ of $\mathrm{FeCl}_{3} \cdot 6 \mathrm{H}_{2} \mathrm{O}$ was dissolved in the mixture and stirred for 30 min under $\mathrm{N}_{2}$ flux at $80{ }^{\circ} \mathrm{C}$, then $50 \mathrm{~mL}$ of $\mathrm{NaOH}$ (1.6 mol/L) solution was pumped into the mixture solution at a constant rate $(0.5$ or $2 \mathrm{~mL} / \mathrm{min})$ and stirred under $\mathrm{N}_{2}$ atmosphere for times varying from 2 to $4 \mathrm{~h}$. After the reaction, the suspension was centrifuged and washed thoroughly in ethanol and water. Finally, the solid product was dried in a hot air oven (Termaks) for $24 \mathrm{~h}$ at $60{ }^{\circ} \mathrm{C}$.

\section{Characterisation of adsorbent}

$\mathrm{MT} / \mathrm{Fe}_{3} \mathrm{O}_{4}$ nanocomposites synthesised in different conditions were thoroughly characterised using different techniques. The phase identification was done by X-ray Diffraction (XRD) in a PANalytical X-ray diffractometer using Co $\mathrm{K} \alpha$ irradiation at $\lambda=1.79 \AA$ with $2 \theta$ ranging from $5^{\circ}$ to $80^{\circ}$ at $40 \mathrm{kV}$ and $40 \mathrm{~mA}$. The magnetic features of the synthesised adsorbents were characterised using a vibrating sample magnetometer (VSM, Princeton Measurements Micromag Model 3900); the field applied ranged from $-1.2 \mathrm{~T}$ to $1.2 \mathrm{~T}$. Transmission electron microscopy (TEM) was conducted using a Hitachi HT-7700 at $100 \mathrm{kV}$. Its morphological and 
elemental characteristics were evaluated through scanning electron microscopy (SEM) and energy-dispersive X-ray spectroscopy (EDS) in a Hitachi S-4800 microscope at $20 \mathrm{kV}$. Surface functional groups were identified by Fourier transform infrared spectroscopy (FTIR) using the Bruker Vertex 70 model in a spectra range of $4000-400 \mathrm{~cm}^{-1}$. X-ray photoelectron spectroscopy (XPS) was done using a Thermo Fisher Scientific ESCALAB 250Xi (Thermo Fisher Scientific, UK), with an X-ray source of monochromatic $\mathrm{Al} \mathrm{K} \alpha$ $(1486.6 \mathrm{eV})$. The specific surface area and pore size distribution were determined by the $\mathrm{N}_{2}$ Adsorption-desorption Isotherm (Tristar ${ }^{\circledR}$ II Plus). Samples were degassed at $60{ }^{\circ} \mathrm{C}$ under $\mathrm{N}_{2}$ overnight and analysed using liquid nitrogen $(77 \mathrm{~K})$. The surface charge was investigated through a Surface Zeta Potential $(\zeta)$ study using a Malvern Zeta sizer Nano ZEN350 model; a $2 \mathrm{mg}$ sample was dispersed in $10 \mathrm{~mL}$ of deionised water, and the $\mathrm{pH}$ was adjusted to $1-10$ by $\mathrm{HCl}$ and $\mathrm{NaOH}$.

\section{Batch adsorption experiments for ammonium removal}

The stock solution of ammonium was prepared by dissolving $\mathrm{NH}_{4} \mathrm{Cl}$ in deionised water as $1,000 \mathrm{mg} / \mathrm{L}$. The working solutions with desired concentrations were diluted from the stock solution. All the adsorption experiments were conducted using $15 \mathrm{~mL}$ tubes by mixing $10 \mathrm{~mL}$ of working solutions with known amounts of adsorbent. The tubes were shaken in an orbital shaker (IKA KS 4000 ic control) at a speed of $300 \mathrm{rpm}$ for a given time at $25^{\circ} \mathrm{C}$ or $35^{\circ} \mathrm{C}$. After shaking, the mixture was filtered using a $0.45 \mu \mathrm{m}$ cellulose acetate syringe filter and analysed through Ion Chromatography (IC, Shimadzu; Shodex IC YS-50 column, column oven temperature $40{ }^{\circ} \mathrm{C}, 4 \mathrm{mM}$ methanesulphonic acid eluent, pump flow $1 \mathrm{~mL} / \mathrm{min}$ ) for the concentrations of ammonium. The iron leaching from the adsorbents under different initial $\mathrm{pH}$ was analysed by inductively coupled plasma-optical emission spectrometry (ICP-OES, Thermo iCAP 6300 series) to determine the concentrations of iron in the treated solution after adsorption. The effects of adsorbent dosage, contact time, initial concentration and initial $\mathrm{pH}$ of working solutions were studied. The initial $\mathrm{pH}$ of working solutions was investigated in a range of 2 to 12 and adjusted by adding $\mathrm{HCl}(1 \mathrm{M}$ and $0.1 \mathrm{M})$ and $\mathrm{NaOH}(1 \mathrm{M}$ and $0.1 \mathrm{M})$. Adsorption experiments were also performed using real stormwater to investigate the efficiency of $\mathrm{MT} / \mathrm{Fe}_{3} \mathrm{O}_{4}$ nanocomposites.

The amount of ammonium adsorbed was calculated from the mass balance, assuming constant liquid phase density:

$q_{\mathrm{e}}=\frac{V^{\mathrm{L}}}{m_{\mathrm{ads}}}\left(C_{0}-C_{\mathrm{e}}\right)$ where $q_{\mathrm{e}}(\mathrm{mg} / \mathrm{g})$ is the adsorbed amount, $V^{\mathrm{L}}(\mathrm{L})$ is the volume of liquid phase, $m_{\text {ads }}(\mathrm{g})$ is the mass of adsorbent, and $C_{0}$ and $C_{\mathrm{e}}(\mathrm{mg} / \mathrm{L})$ are the ammonium concentrations initially and at equilibrium, respectively. The removal efficiency RE was calculated by the following equation:

$\mathrm{RE}=\frac{C_{0}-C_{\mathrm{e}}}{C_{0}} \times 100 \%$

\section{Results and discussion}

\section{Preliminary adsorption experiments}

Several batches of nanocomposite adsorbents were prepared by varying the amount of MT, the reaction time, and the flow rate of $\mathrm{NaOH}$ addition as listed in Table 1 . The table also shows the preliminary characterisation of the surface area using the BET method.

Preliminary adsorption tests were conducted to determine the adsorbent batch with the highest uptake of $\mathrm{NH}_{4}{ }^{+}$. The initial $\mathrm{NH}_{4}{ }^{+}$concentration was $50 \mathrm{mg} / \mathrm{L}$, and the solid-toliquid phase ratio was kept low $(1: 500 \mathrm{~g} / \mathrm{L})$ to avoid adsorbing all of ammonium which would yield only small differences in uptake between the adsorbent batches. Both the original MT and the prepared $\mathrm{Fe}_{3} \mathrm{O}_{4}$ showed limited removal efficiency of $\mathrm{NH}_{4}{ }^{+}$at $4.90 \%$ and $2.52 \%$, respectively, while the synthesised adsorbents were able to remove $\mathrm{NH}_{4}{ }^{+}$with various efficiencies ranging from $16.58 \%$ to $37.20 \%$.

The performance of the synthesised adsorbents with respect to $\mathrm{NH}_{4}{ }^{+}$adsorption increased with retention time and the amount of MT used during synthesis. A possible reason for this is that the longer retention time ensures

Table 1 Adsorbent batches synthesised

\begin{tabular}{llllll}
\hline $\begin{array}{l}\mathrm{MT} / \mathrm{Fe}_{3} \mathrm{O}_{4} \\
\text { ID }\end{array}$ & MT (g) & Time (h) $\begin{array}{l}\mathrm{NaOH} \\
(\mathrm{mL} / \\
\mathrm{min})\end{array}$ & $S_{\mathrm{BET}}\left(\mathrm{m}^{2} / \mathrm{g}\right)^{*}$ & $R E(\%)^{* *}$ \\
\hline $\mathrm{Fe}_{3} \mathrm{O}_{4}$ & - & - & - & 37.66 & 4.90 \\
$\mathrm{MT}$ & - & - & - & 245.99 & 2.52 \\
517 & 1.0 & 2 & 0.5 & 92.86 & 16.58 \\
522 & 2.0 & 2 & 0.5 & 129.65 & 17.61 \\
529 & 3.0 & 2 & 0.5 & 122.70 & 25.29 \\
528 & 3.0 & 4 & 0.5 & 128.68 & 28.70 \\
603 & 4.0 & 4 & 0.5 & 88.22 & 30.34 \\
604 & 4.0 & 4 & 2 & 100.17 & 37.20 \\
605 & 5.0 & 4 & 0.5 & 98.16 & 32.33 \\
610 & 5.0 & 4 & 2 & 123.32 & 24.73 \\
\hline
\end{tabular}

* Specific surface area (BET)

**Solid-to-liquid phase ratio 1:500, initial $\mathrm{NH}_{4}^{+}$concentration $50 \mathrm{mg} / \mathrm{L}$ 
better dispersion of $\mathrm{Fe}_{3} \mathrm{O}_{4}$ on the surface of the MT. The higher flow rates of $\mathrm{NaOH}$ pumped to the reaction lead to higher specific surface area $\left(\mathrm{S}_{\mathrm{BET}}\right)$, but the $\mathrm{NH}_{4}{ }^{+}$uptake ability changes depending on the amount of MT. The obvious improvement of the $\mathrm{NH}_{4}{ }^{+}$uptake ability of MT after the modification indicates that the addition of iron creates and stimulates new active sites. However, excessive $\mathrm{Fe}_{3} \mathrm{O}_{4}$ may cover partial active sites resulting in lower removal efficiency of $\mathrm{NH}_{4}{ }^{+}$. As shown in Table $1, \mathrm{MT} / \mathrm{Fe}_{3} \mathrm{O}_{4} 604$ has the highest adsorption towards $\mathrm{NH}_{4}{ }^{+}$. Therefore, further studies were conducted with sample $\mathrm{MT} / \mathrm{Fe}_{3} \mathrm{O}_{4} 604$ and reaction conditions were optimised for the enhancement of ammonium removal efficiency. The spent (ammonium loaded) adsorbent was then named $\mathrm{MT} / \mathrm{Fe}_{3} \mathrm{O}_{4} 604 \mathrm{~N}$.

\section{Characterisation of $\mathrm{MT} / \mathrm{Fe}_{3} \mathrm{O}_{4}$ nanocomposites}

\section{Structure and magnetic properties}

The crystal structures of MT, $\mathrm{Fe}_{3} \mathrm{O}_{4}$, and $\mathrm{MT} / \mathrm{Fe}_{3} \mathrm{O}_{4}$ were investigated via $\mathrm{XRD}$; the diffraction patterns (converted from $\mathrm{Co} \mathrm{K} \alpha$ to $\mathrm{Cu} \mathrm{K} \alpha$ ) are shown in Fig. 1a. The seven strong peaks at $18.3^{\circ}, 30.1^{\circ}, 35.5^{\circ}, 43.1^{\circ}, 53.5^{\circ}, 57.0^{\circ}$, and $62.7^{\circ}$ corresponded to the cubic inverse spinel structure of $\mathrm{Fe}_{3} \mathrm{O}_{4}$, which was synthesised through co-precipitation of $\mathrm{Fe}^{2+}$ and $\mathrm{Fe}^{3+}[19,26-28]$. The diffraction peaks at $8.8^{\circ}$, $17.8^{\circ}, 19.8^{\circ}, 35.1^{\circ}$, and $45.5^{\circ}$ corresponded to MT (montmorillonite K10), which were well matched with the reported spectra [29-31]. Quartz is present in MT, evidenced by the pattern at $20.8^{\circ}, 26.6^{\circ}, 50.1^{\circ}$, and $60.0^{\circ}$ [32]. The spectra of $\mathrm{MT} / \mathrm{Fe}_{3} \mathrm{O}_{4} 604$ and $\mathrm{MT} / \mathrm{Fe}_{3} \mathrm{O}_{4} 604 \mathrm{~N}$ were almost the same as MT, suggesting that neither the modification by $\mathrm{Fe}_{3} \mathrm{O}_{4}$ nor the adsorption of $\mathrm{NH}_{4}{ }^{+}$changed the crystal structure of MT. All the other $\mathrm{MT} / \mathrm{Fe}_{3} \mathrm{O}_{4}$ nanocomposites expressed identical patterns, as shown in Fig. S1 in the Supplementary Document. The peak of $\mathrm{Fe}_{3} \mathrm{O}_{4}$ at $35.5^{\circ}$, presented beside the MT $35.1^{\circ}$ (110) peak in the spectra of $\mathrm{MT} / \mathrm{Fe}_{3} \mathrm{O}_{4} 604$ and $\mathrm{MT} / \mathrm{Fe}_{3} \mathrm{O}_{4} 604 \mathrm{~N}$, indicated that the (110) plane of MT/ $\mathrm{Fe}_{3} \mathrm{O}_{4}$ became more disordered than that of MT due to the loading of $\mathrm{Fe}_{3} \mathrm{O}_{4}$.

The magnetic properties of the prepared $\mathrm{MT} / \mathrm{Fe}_{3} \mathrm{O}_{4}$ products were evaluated by VSM, as shown in Figs. $1 \mathrm{~b}$ and S2. All of the products exhibited superparamagnetic properties with extremely narrow hysteresis loops [33, 34]. Moreover, sample $\mathrm{MT} / \mathrm{Fe}_{3} \mathrm{O}_{4} 517$ (Fig. S2) had a relatively high saturation magnetisation, which is favourable for magnetic separation. The $\mathrm{Fe}_{3} \mathrm{O}_{4}$ aggregated to larger sizes due to the relatively high amount of it, resulting in low removal efficiency of $\mathrm{MT} / \mathrm{Fe}_{3} \mathrm{O}_{4}$ 517. It was not selected as the sample to be further studied since the more important property is the high adsorption capacity. Although the magnetic moments of the products are relatively low, their magnetic feature can accelerate separation in the after-adsorption processes.
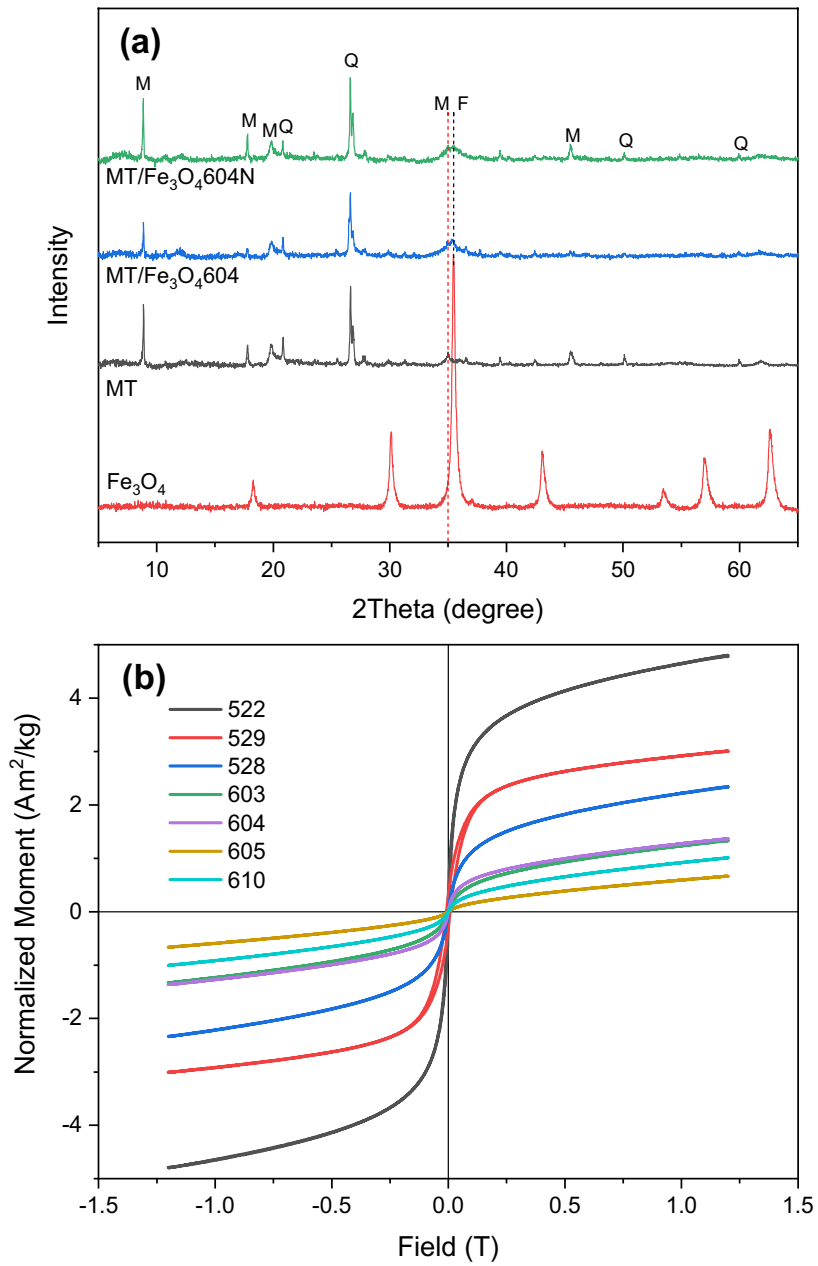

Fig. 1 a XRD patterns (M: montmorillonite, Q: quartz, $\mathrm{F}: \mathrm{Fe}_{3} \mathrm{O}_{4}$ ), b hysteresis loops of the synthesised adsorbents. See Fig. S2 for data on sample 517

\section{Morphology and composition analysis}

The TEM images showed the sheet-like nature and small number of rod-like structures of MT (Fig. 2a) as well as the $\mathrm{Fe}_{3} \mathrm{O}_{4}$ nanoparticles and aggregates (Fig. 2b). The sizes of the $\mathrm{Fe}_{3} \mathrm{O}_{4}$ nanoparticles were around $15-25 \mathrm{~nm}$, as shown in Fig. 2b. Similarly sized $\mathrm{Fe}_{3} \mathrm{O}_{4}$ nanoparticles were observed in the $\mathrm{MT} / \mathrm{Fe}_{3} \mathrm{O}_{4}$ nanocomposites, as shown in Fig. 2c. The $\mathrm{Fe}_{3} \mathrm{O}_{4}$ nanoparticles were either dispersed on the surface and around the rod-like structures or intercalated between the layers of MT (Fig. 2c). This observation is confirmed by a SEM image of $\mathrm{MT} / \mathrm{Fe}_{3} \mathrm{O}_{4} 604$, as shown in Fig. 3c.

The morphologies of the representative samples were characterised by SEM, as shown in Fig. 3a-d. MT (Fig. 3a) had a shape of flakes and a layered, relatively smooth surface, while the $\mathrm{Fe}_{3} \mathrm{O}_{4}$ was in the shape of granules and seen on the surface of modified MT (Fig. 3c); this is direct evidence of the successful synthesis of $\mathrm{MT} / \mathrm{Fe}_{3} \mathrm{O}_{4}$ 


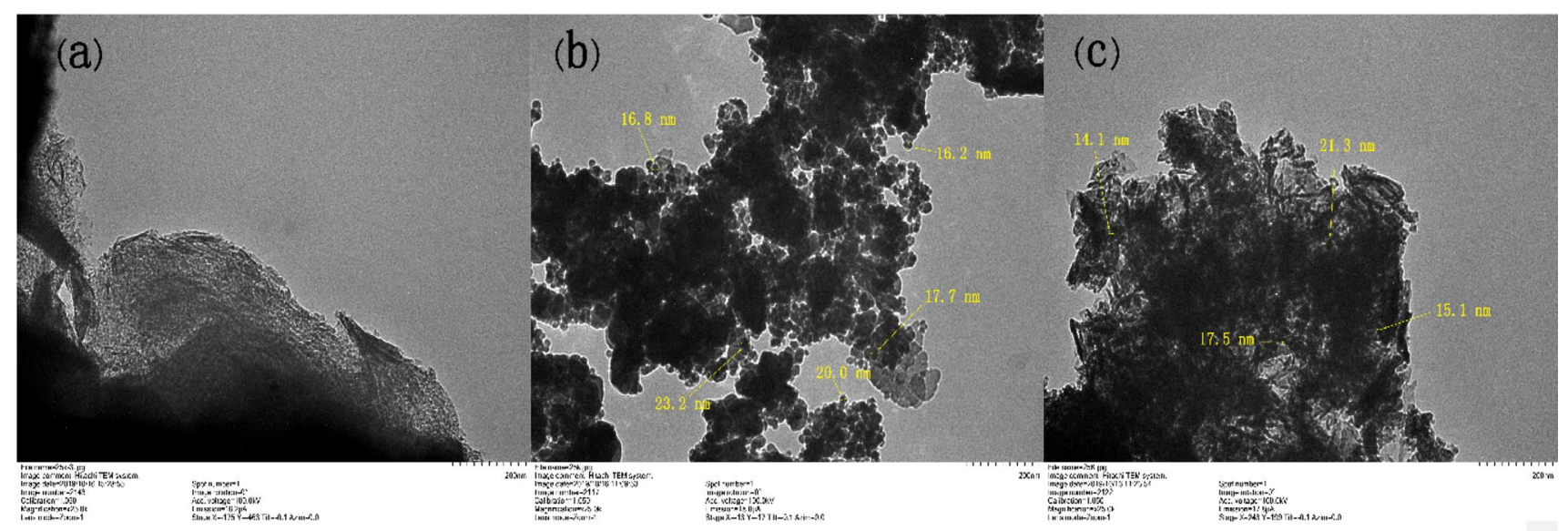

Fig. 2 TEM images of a MT, b Fe $\mathrm{O}_{4}, \mathbf{c} \mathrm{MT} / \mathrm{Fe}_{3} \mathrm{O}_{4} 604$

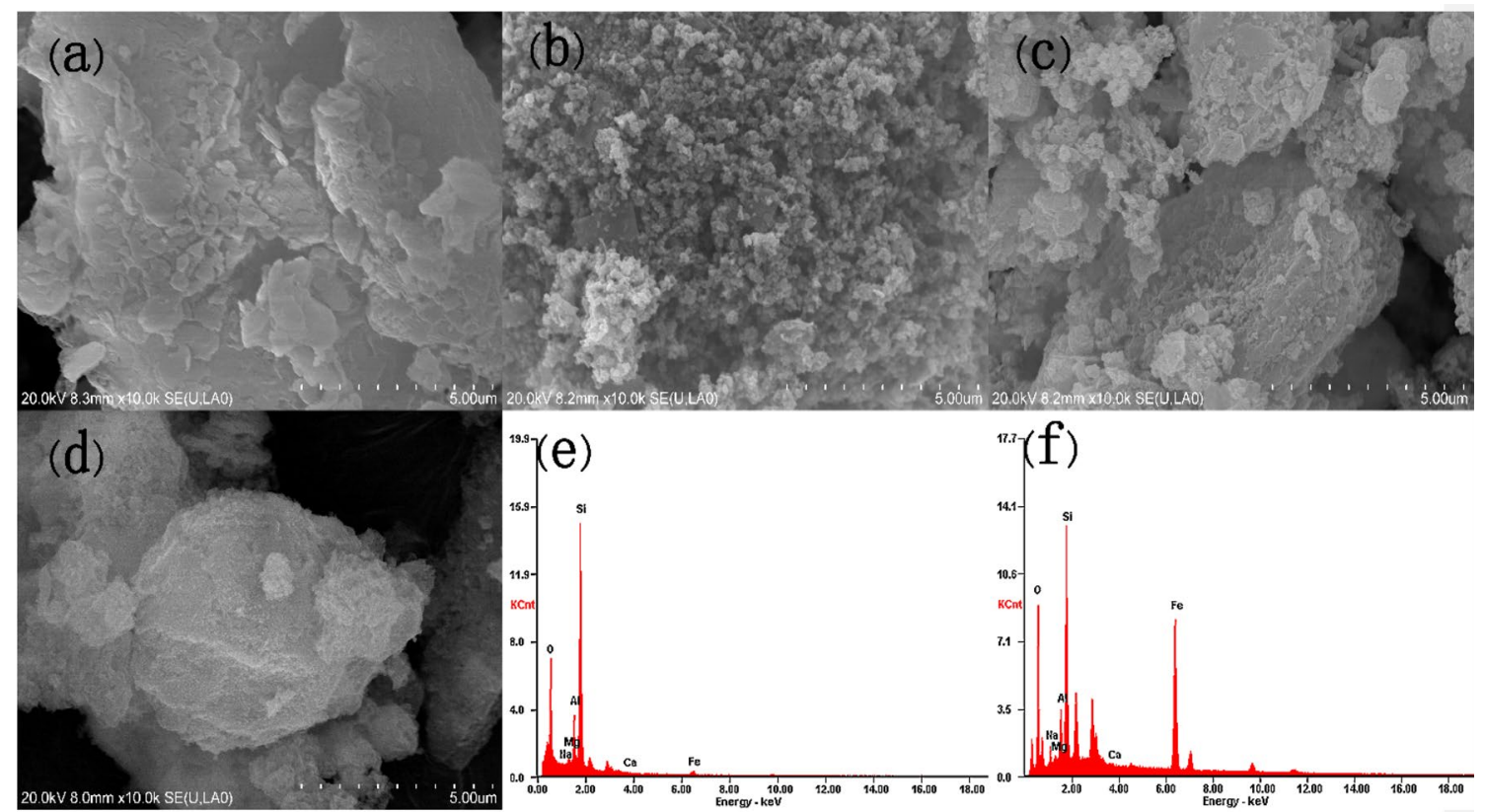

Fig. 3 SEM images of a MT, b Fe $\mathrm{O}_{4}, \mathbf{c} \mathrm{MT} / \mathrm{Fe}_{3} \mathrm{O}_{4} 604$, $\mathbf{d ~ M T / F e} \mathrm{O}_{4} \mathrm{O}_{4} 604 \mathrm{~N}$, EDS plots of e MT, $\mathbf{f} \mathrm{MT} / \mathrm{Fe}_{3} \mathrm{O}_{4} 604$

nanocomposite [35]. The fine $\mathrm{Fe}_{3} \mathrm{O}_{4}$ particles adhere to the surface of MT as shown in Fig. 3c. The existence of Fe was confirmed by the EDS results (Fig. 3e-f), as the Fe content increased markedly in $\mathrm{MT} / \mathrm{Fe}_{3} \mathrm{O}_{4} 604$ compared to MT. After the adsorption process, the structure of $\mathrm{MT} / \mathrm{Fe}_{3} \mathrm{O}_{4} 604 \mathrm{~N}$ (Fig. 3d) was not significantly changed in compare with $\mathrm{MT} / \mathrm{Fe}_{3} \mathrm{O}_{4} 604$ (Fig. 3c), except for that the surface of MT/ $\mathrm{Fe}_{3} \mathrm{O}_{4} 604 \mathrm{~N}$ (Fig. 3d) was less covered by $\mathrm{Fe}_{3} \mathrm{O}_{4}$ particles which was corresponded by the iron leaching phenomenon (Fig. 6a).

The surface composition was analysed by XPS, as shown in Fig. 4a-b. Peaks at $724.9 \mathrm{eV}$ and $711.4 \mathrm{eV}$ - as two typical spectra of $\mathrm{Fe} 2 \mathrm{p}_{1 / 2}$ and $\mathrm{Fe} 2 \mathrm{p}_{3 / 2}$, respectively—confirmed the existence of $\mathrm{Fe}_{3} \mathrm{O}_{4}$ in the as-synthesised adsorbents [36, 37]. The Mg 1s peak was present in the spectrum of MT, but barely showed after modification, indicating that Fe took the place of $\mathrm{Mg}$. As expected, $\mathrm{N} 1 \mathrm{~s}$ appeared in the spectrum of $\mathrm{MT} / \mathrm{Fe}_{3} \mathrm{O}_{4} 604 \mathrm{~N}$ after adsorption, as evidence of the existence of $\mathrm{NH}_{4}{ }^{+}$on the surface of the $\mathrm{MT} / \mathrm{Fe}_{3} \mathrm{O}_{4}$ nanocomposite. The characteristic peak of $\mathrm{Si} 2 \mathrm{p}$ verified the composition of MT [20]. The binding energy of Si 2p increased by $1.2 \mathrm{eV}$ from MT to $\mathrm{MT} / \mathrm{Fe}_{3} \mathrm{O}_{4} 604$, indicating a strong interaction between $\mathrm{Si}$ and $\mathrm{Fe}$ atoms. The lowered intensity of $\mathrm{Si} 2 \mathrm{p}$ in $\mathrm{MT} / \mathrm{Fe}_{3} \mathrm{O}_{4}$ nanocomposite compared with MT suggests that partial $\mathrm{Si}$ sites were covered by $\mathrm{Fe}_{3} \mathrm{O}_{4}$. The $\mathrm{Na} 1 \mathrm{~s}$ was not observed in MT but appeared clearly in the $\mathrm{MT} / \mathrm{Fe}_{3} \mathrm{O}_{4}$ 

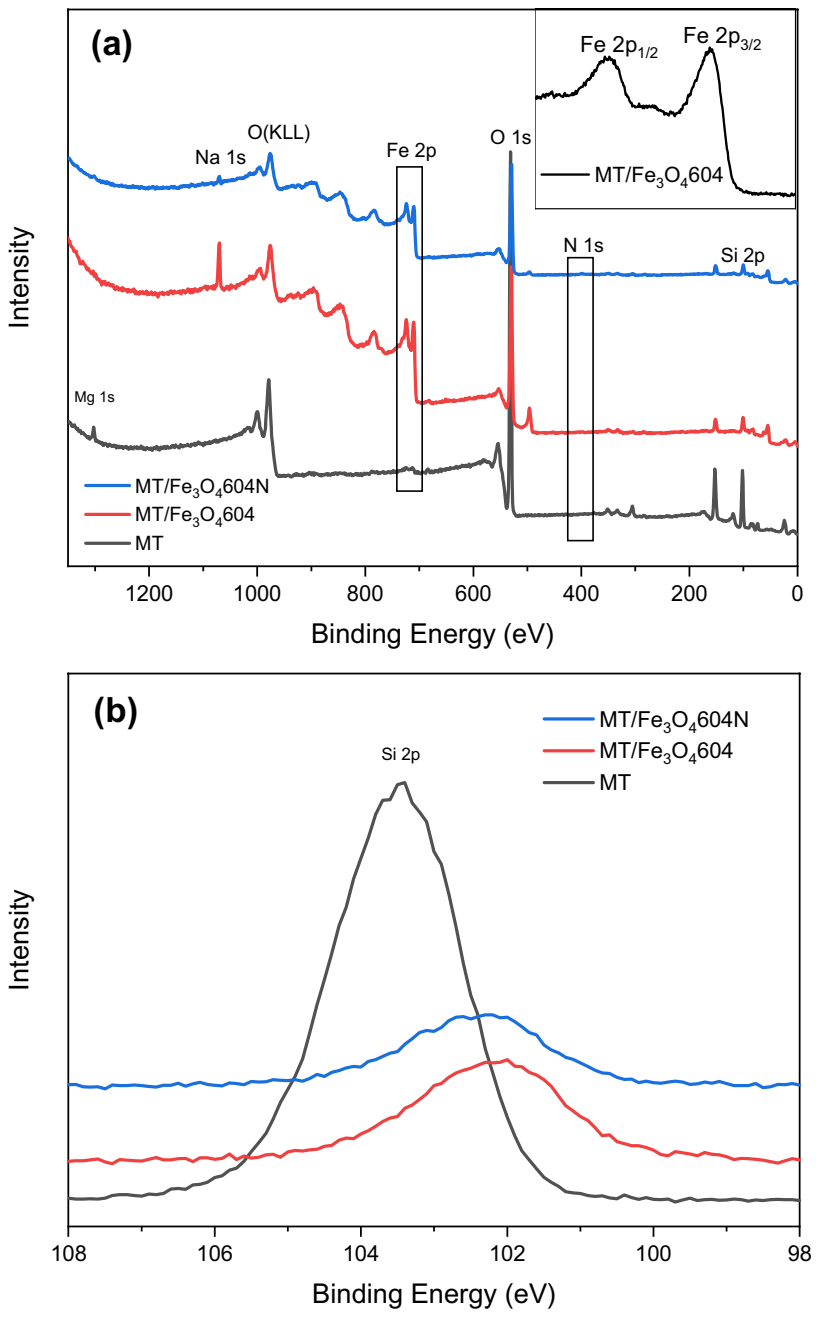

Fig. 4 XPS spectra of adsorbent materials a survey, b Si 2p

nanocomposite (Fig. S3), coming from the $\mathrm{NaOH}$ used in the modification. During the adsorption process, Na was released to the aqueous solution, so there was a low-intensity peak of $\mathrm{Na} 1 \mathrm{~s}$ in the used adsorbent $\left(\mathrm{MT} / \mathrm{Fe}_{3} \mathrm{O}_{4} 604 \mathrm{~N}\right)$.

The infrared spectra of $\mathrm{MT}, \mathrm{Fe}_{3} \mathrm{O}_{4}$ and the adsorbent before and after the adsorption of $\mathrm{NH}_{4}{ }^{+}$are shown in Fig. $5 \mathrm{a}$. The band at $544 \mathrm{~cm}^{-1}$ in the spectra of $\mathrm{Fe}_{3} \mathrm{O}_{4}$ corresponds to the characteristic band of magnetite, which is attributed to the mixture of $\mathrm{Fe}^{2+}$ and $\mathrm{Fe}^{3+}$ in the sample $[38,39]$. The characteristic strong bands at 1,031 and $449 \mathrm{~cm}^{-1}$ of MT are assigned to the stretching of $\mathrm{Si}-\mathrm{O}$. The $\mathrm{Si}-\mathrm{O}$ bands are present in the spectra of modified samples at around $1000 \mathrm{~cm}^{-1}$. The bands showed at around 3600 and $1630 \mathrm{~cm}^{-1}$ are related to the stretching and bending of hydroxyl groups, respectively $[40,41]$. The shifting of $\mathrm{Si}-\mathrm{O}$ and hydroxyl groups from MT to MT/ $/ \mathrm{Fe}_{3} \mathrm{O}_{4} 604$ indicated that the loaded $\mathrm{Fe}_{3} \mathrm{O}_{4}$ encountered these groups on the surface of MT. One new band appeared in the spectra of the after-adsorption sample at $1,443 \mathrm{~cm}^{-1}$ due to the deformation of $\mathrm{NH}_{4}^{+}$, indicating
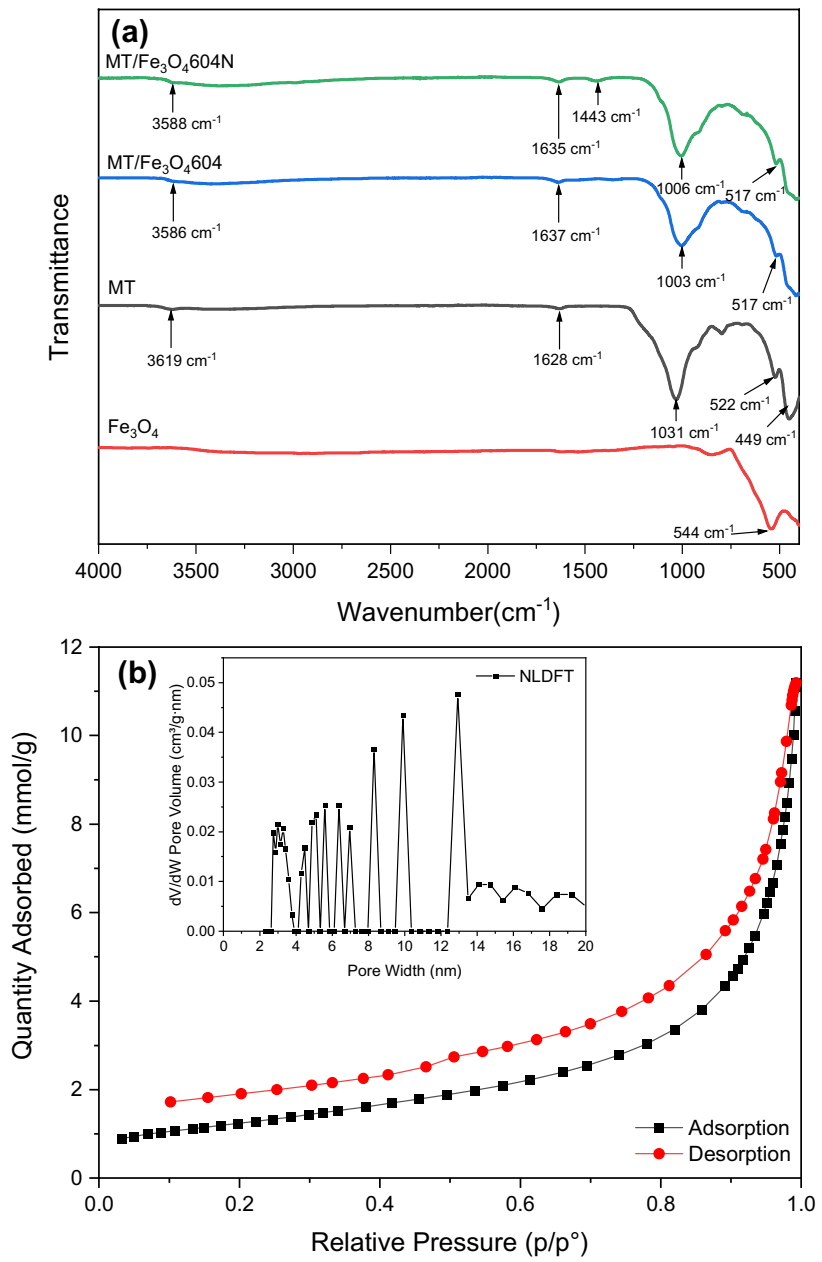

Fig. 5 a FTIR spectra of $\mathrm{Fe}_{3} \mathrm{O}_{4}, \mathrm{MT}, \mathrm{MT} / \mathrm{Fe}_{3} \mathrm{O}_{4} 604$, and MT/ $\mathrm{Fe}_{3} \mathrm{O}_{4} 604 \mathrm{~N}$, b $\mathrm{N}_{2}$ adsorption-desorption isotherm and NLDFT pore size distribution of $\mathrm{MT} / \mathrm{Fe}_{3} \mathrm{O}_{4} 604$

that chemisorption of $\mathrm{NH}_{4}{ }^{+}$happened during the contact [15]. The bands at around $520 \mathrm{~cm}^{-1}$ are attributed to the vibrations of the $\mathrm{Si}-\mathrm{O}-\mathrm{Al}$ structure [20].

\section{Specific surface area and pore size analysis}

According to IUPAC classification, the $\mathrm{N}_{2}$ adsorption-desorption isotherm of $\mathrm{MT} / \mathrm{Fe}_{3} \mathrm{O}_{4} 604$ (Fig. 5b) is a Type IV physisorption isotherm and Type $\mathrm{H} 3$ hysteresis loop, given by non-rigid aggregates of plate-like particles; in this case, it is montmorillonite, with slit-shaped pores. The Kelvin equation-based Barrett-Joyner-Halenda (BJH) method would underestimate the pore size for narrow mesopores, so the non-local-density functional theory (NLDFT)-based method was applied to obtain a more reliable assessment of pore size distribution [42]. As shown in Fig. 5b, the pore sizes of $\mathrm{MT} / \mathrm{Fe}_{3} \mathrm{O}_{4} 604$ are distributed in the range of narrow mesopores, which are in the range of 3-13 nm. The particle size of $\mathrm{MT} / \mathrm{Fe} 3 \mathrm{O} 4604$ was analysed by Zeta sizer, found to 
be $609.4 \mathrm{~nm}$ in diameter. The physical dimensions of the pores suggest a good molecular sieving effect, which indicate that the nanocomposite can be used as a filling material to be dispersed into polymer matrices of membranes for a better separation performance in water treatment [43, 44].

The $\mathrm{S}_{\mathrm{BET}}$ was calculated by the Brunauer-Emmett-Teller (BET) method and listed in Table 1. The raw MT has the highest $\mathrm{S}_{\mathrm{BET}}$ of $245.99 \mathrm{~m}^{2} / \mathrm{g}$, while all the $\mathrm{MT} / \mathrm{Fe}_{3} \mathrm{O}_{4}$ nanocomposites have lower $\mathrm{S}_{\mathrm{BET}}$. There is no clear trend of surface area among the prepared adsorbent samples based on the MT amount for the reaction, but the flow rate of $\mathrm{NaOH}$ affected the $\mathrm{S}_{\mathrm{BET}}$ in a such a way that the higher flow rate $\left(2 \mathrm{~mL} / \mathrm{min}\right.$ ) led to a higher $\mathrm{S}_{\mathrm{BET}}$ than that of the lower flow rate $(0.5 \mathrm{~mL} / \mathrm{min})$ when the MT amount and retention time were the same.

This is possibly due to the behaviour of $\mathrm{Fe}_{3} \mathrm{O}_{4}$ aggregates on the MT surface; more $\mathrm{Fe}_{3} \mathrm{O}_{4}$ was formed inside the pores of MT at a lower rate. The results also suggested that the adsorptive property need not always be positively correlated to the specific surface area. It is noteworthy that the best adsorption capacity was obtained with $\mathrm{MT} / \mathrm{Fe}_{3} \mathrm{O}_{4} 604$ even though the highest $\mathrm{S}_{\mathrm{BET}}$ was attained with $\mathrm{MT} / \mathrm{Fe}_{3} \mathrm{O}_{4} 522$. The main difference is higher MT/Fe ratio and longer reaction time in the synthesis of $\mathrm{MT} / \mathrm{Fe}_{3} \mathrm{O}_{4} 604$.

\section{Adsorption mechanism and kinetics}

\section{Adsorption mechanism}

A series of adsorption equilibrium studies were performed with initial $\mathrm{NH}_{4}{ }^{+}$concentrations of 10 to $80 \mathrm{mg} / \mathrm{L}$ at 25 and $35{ }^{\circ} \mathrm{C}$. These are typical ambient temperatures in many geographic regions. Higher temperatures were not studied because the high energy requirement for stormwater heating was not economic. The concentrations of $\mathrm{NH}_{4}{ }^{+}$in stormwater vary throughout seasons. Therefore, concentrations ranging up to $80 \mathrm{mg} / \mathrm{L}$ were appropriate.

$\mathrm{NH}_{4}{ }^{+}$uptake increased with increasing initial concentration of $\mathrm{NH}_{4}^{+}$(Fig. 6b), meaning that some of the available active sites remain unoccupied at lower $\mathrm{NH}_{4}{ }^{+}$concentrations. Similar results were observed in other studies on the adsorption of $\mathrm{NH}_{4}{ }^{+}$by clay and $\mathrm{Fe}_{3} \mathrm{O}_{4}$ materials $[45,46]$. Additionally, higher equilibrium loading was achieved at $35^{\circ} \mathrm{C}$ than at $25^{\circ} \mathrm{C}$, which suggests that the adsorption process is endothermic.

The $\mathrm{pH}$ of the $\mathrm{NH}_{4}{ }^{+}$solution influences the adsorption process. Therefore, the adsorption of ammonium ions by $\mathrm{MT} / \mathrm{Fe}_{3} \mathrm{O}_{4} 604$ was also investigated in different $\mathrm{pH}$ ranges. $50 \mathrm{mg} / \mathrm{L} \mathrm{NH}_{4}{ }^{+}$solution was adjusted to an initial $\mathrm{pH}$ of $2,4,6,7,8,10$, and 12 , respectively, and contacted with $\mathrm{MT} / \mathrm{Fe}_{3} \mathrm{O}_{4} 604$ through shaking at $300 \mathrm{rpm}$ for $60 \mathrm{~min}$ at $25{ }^{\circ} \mathrm{C}$. As shown in Fig. 6 a, the abundant $\mathrm{H}^{+}$ions inhibited the adsorption of $\mathrm{NH}_{4}{ }^{+}$in highly acidic conditions $(\mathrm{pH} 2)$ through competitive adsorption [47] while the adsorption amounts of $\mathrm{NH}_{4}{ }^{+}$under other $\mathrm{pH}$ conditions are affected to some extent. This may have been because the added adsorbents affected the $\mathrm{pH}$ of the solutions, resulting in a reduction in the effect of the initial $\mathrm{pH}$ of the $\mathrm{NH}_{4}^{+}$solutions on the adsorption behaviour.

A possible issue with the nanocomposite adsorbent is dissolution of iron. A high solid-to-liquid phase ratio of 1:4 was used to observe this phenomenon even if leaching was low. As observed in Fig. 6a, iron leaching was significant at $\mathrm{pH} 2(51.3 \mathrm{mg} / \mathrm{L})$ but negligible at $\mathrm{pH}$ ranging from 4 to 10 $(<0.85 \mathrm{mg} / \mathrm{L})$. Leaching of iron increased again under alka-

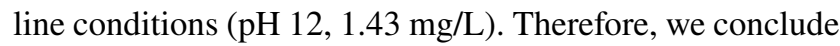
that the nanocomposite adsorbents are stable at the $\mathrm{pH}$ range of their most likely applications.

The cations in the MT framework contributed to the removal of $\mathrm{NH}_{4}{ }^{+}$by $\mathrm{MT} / \mathrm{Fe}_{3} \mathrm{O}_{4}$ nanocomposite through ion
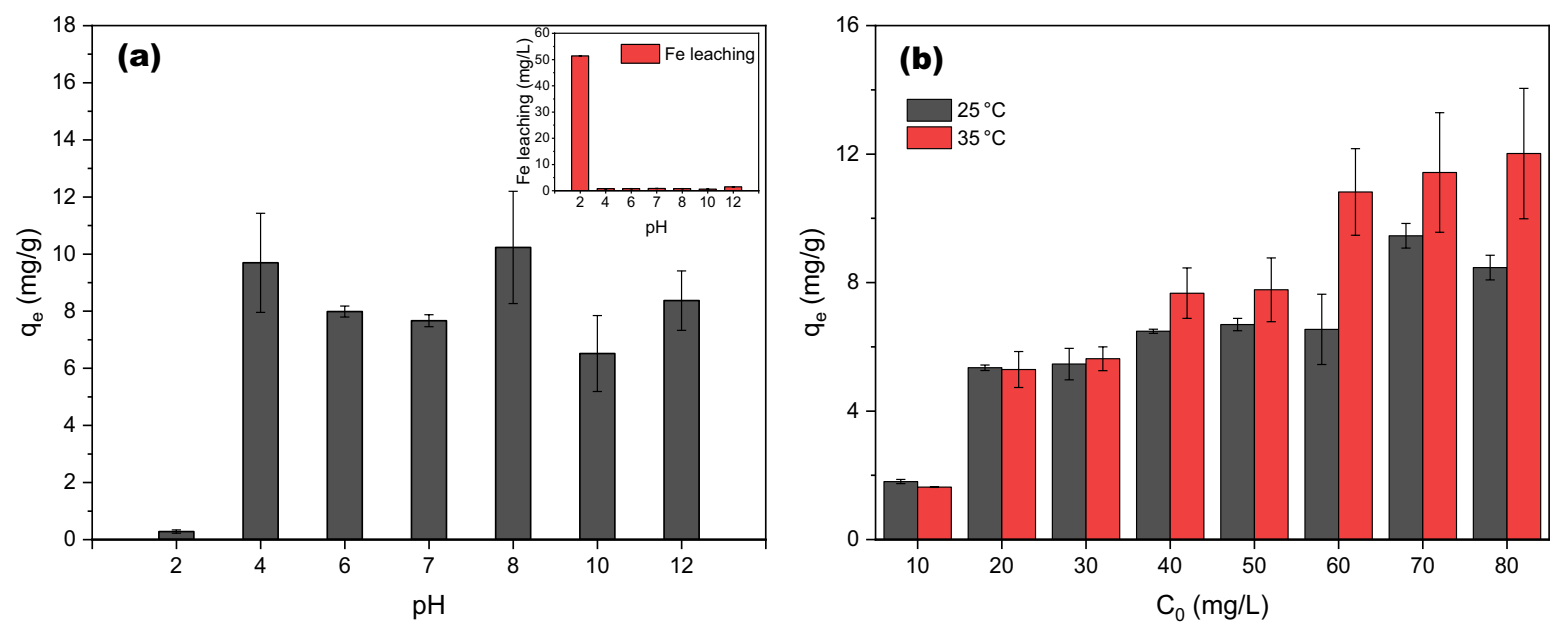

Fig. 6 Influence of $\mathrm{pH}$ and temperature on adsorption of ammonium at initial concentrations of 10 to $80 \mathrm{mg} / \mathrm{L}$ at $25^{\circ} \mathrm{C}$ and $35^{\circ} \mathrm{C}$ 
exchange $[48,49]$. It was indicated in the results of XPS and stormwater test that $\mathrm{Na}^{+}$took the role of ion exchange during the contact of $\mathrm{MT} / \mathrm{Fe}_{3} \mathrm{O}_{4} 604$ and the $\mathrm{NH}_{4}{ }^{+}$-containing solution. Meanwhile, co-existing cations such as $\mathrm{K}^{+}, \mathrm{Mg}^{2+}$, and $\mathrm{Ca}^{2+}$ worked as competitive cations during the removal of $\mathrm{NH}_{4}^{+}$.

As shown in Fig. 7a, we further investigated the zeta potential $(\zeta)$ of $\mathrm{MT}, \mathrm{Fe}_{3} \mathrm{O}_{4}$, and $\mathrm{MT} / \mathrm{Fe}_{3} \mathrm{O}_{4} 604$, dispersing it in deionised water at different $\mathrm{pH}$ values. The surface charge features of MT were in accordance with the literature [15]. The loading of $\mathrm{Fe}_{3} \mathrm{O}_{4}$ particles changed the zeta potential variation of MT. The isoelectric point ( $\mathrm{pH}$ point of zero charge, $\mathrm{pH}_{\mathrm{pzc}}$ ) of MT/ $/ \mathrm{Fe}_{3} \mathrm{O}_{4} 604$ was 5.01, close to that of $\mathrm{Fe}_{3} \mathrm{O}_{4}$, which was 4.80. The similarity of $\mathrm{MT} / \mathrm{Fe}_{3} \mathrm{O}_{4} 604$ and $\mathrm{Fe}_{3} \mathrm{O}_{4}$ revealed the successful coating of $\mathrm{Fe}_{3} \mathrm{O}_{4}$ on the surface of MT [50]. At $\mathrm{pH}>\mathrm{pH}_{\mathrm{pzc}}, \mathrm{MT} / \mathrm{Fe}_{3} \mathrm{O}_{4} 604$ was negatively charged, which is favourable for electrostatic interaction with cationic $\mathrm{NH}_{4}{ }^{+}$ [51].

Based on the analysis above, the mechanism (Scheme 1) of the uptake of $\mathrm{NH}_{4}{ }^{+}$by the $\mathrm{MT} / \mathrm{Fe}_{3} \mathrm{O}_{4}$ nanocomposite may be pictured as the following reactions, which contribute to ion exchange and electrostatic interaction, respectively. The sodium ions $\left(\mathrm{Na}^{+}\right)$existing in the interlayers of $\mathrm{MT} / \mathrm{Fe}_{3} \mathrm{O}_{4}$ nanocomposite exchange with $\mathrm{NH}_{4}{ }^{+}$during the adsorption procedure, as shown in Eq. (3). The $\mathrm{MT} / \mathrm{Fe}_{3} \mathrm{O}_{4}$ nanocomposite exhibits a negative charge at a $\mathrm{pH}$ that is higher than 5 . Thus, $\mathrm{NH}_{4}{ }^{+}$can be captured through electrostatic interaction, Eq. (4).

$$
\begin{aligned}
& \mathrm{Na}-\mathrm{MT} / \mathrm{Fe}_{3} \mathrm{O}_{4}+\mathrm{NH}_{4} \mathrm{Cl} \rightleftharpoons \mathrm{NH}_{4}-\mathrm{MT} / \mathrm{Fe}_{3} \mathrm{O}_{4}+\mathrm{NaCl} \\
& \mathrm{MT} / \mathrm{Fe}_{3} \mathrm{O}_{4}^{-}+\mathrm{NH}_{4}^{+} \rightleftharpoons \mathrm{NH}_{4}^{+} \cdot \mathrm{MT} / \mathrm{Fe}_{3} \mathrm{O}_{4}^{-}
\end{aligned}
$$

\section{Adsorption isotherms}

The adsorption isotherms were studied by correlating them with Langmuir, Freundlich, and Fowler-Guggenheim isotherm models [52-55]. The Langmuir isotherm [56] is written as

$q_{e}=\frac{q_{\mathrm{m}} K_{\mathrm{L}} C_{e}}{1+K_{\mathrm{L}} C_{e}}$

where $C_{\mathrm{e}}(\mathrm{mg} / \mathrm{L})$ is the concentration of $\mathrm{NH}_{4}{ }^{+}$in equilibrium, $q_{\mathrm{e}}(\mathrm{mg} / \mathrm{g})$ and $q_{\mathrm{m}}(\mathrm{mg} / \mathrm{g})$ are the amount of $\mathrm{NH}_{4}{ }^{+}$ adsorbed in equilibrium and the maximum uptake, respectively, and $K_{\mathrm{L}}(\mathrm{L} / \mathrm{mg})$ is the Langmuir constant.

The equation for Freundlich isotherm [57] is

$q_{\mathrm{e}}=K_{\mathrm{f}} C_{e}^{\frac{1}{n}}$

where $n$ represents the heterogeneity factor related to the distribution of interaction energies of adsorption sites, and $K_{\mathrm{f}}\left(\mathrm{mg} / \mathrm{g} \cdot(\mathrm{L} / \mathrm{mg})^{1 / \mathrm{n}}\right)$ is the Freundlich constant.

The Fowler-Guggenheim isotherm (Eq. 7) assumes an energetically homogeneous adsorbent surface like the Langmuir isotherm but includes an additional parameter to describe interactions between adsorbed species. Such interactions can be positive or negative (i.e. lead to increased or decreased surface concentration on the adsorbent). While the model is not explicit, solving Eq. (7) for the equilibrium loading $q_{\mathrm{e}}$ is straightforward with standard numerical methods.

$K_{\mathrm{FG}} C_{\mathrm{e}}=\frac{q_{\mathrm{e}}}{q_{\mathrm{m}}-q_{\mathrm{e}}} \exp \left(-\chi \frac{q_{\mathrm{e}}}{q_{\mathrm{m}}}\right)$

In Eq. (7), $K_{\mathrm{FG}}$ and $q_{\mathrm{m}}$ have the same meaning as the corresponding parameters in the Langmuir isotherm. $\chi$ describes the lateral interactions between adsorbed molecules.

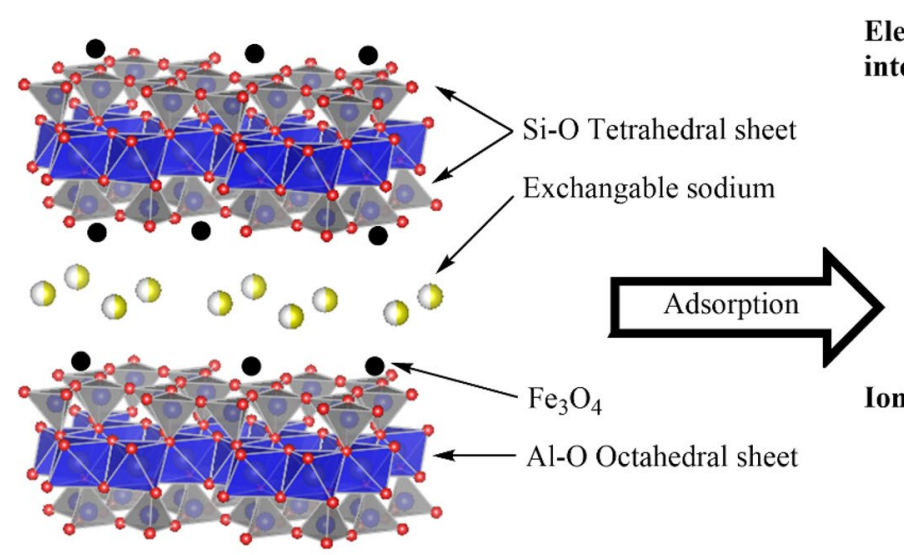

$\mathrm{MT} / \mathrm{Fe}_{3} \mathrm{O}_{4}$ nanocomposite
Electrostatic interaction
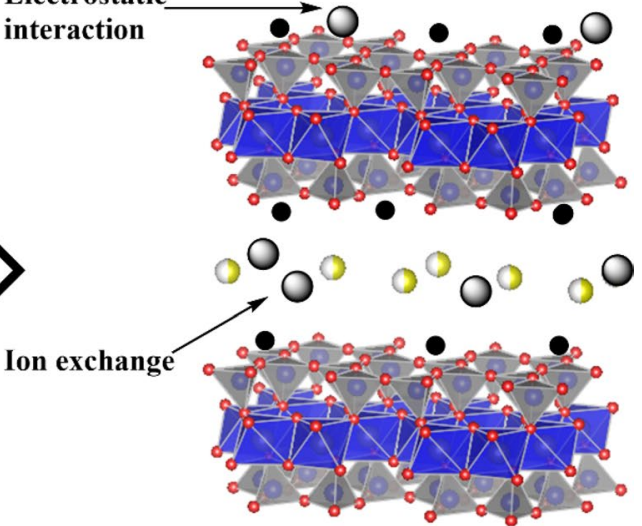

Ammonium $\mathrm{MT} / \mathrm{Fe}_{3} \mathrm{O}_{4}$ nanocomposite

Scheme 1 Mechanism of ammonium adsorption on $\mathrm{MT} / \mathrm{Fe}_{3} \mathrm{O}_{4}$ nanocomposite 
To avoid artefacts arising from linearising the isotherm models and data, the parameters of the isotherm models were fitted with the nonlinear least squares method. The best-fit values are listed in Table 2, and plots for adsorption at $25{ }^{\circ} \mathrm{C}$ are shown in Fig. 7b. The Langmuir isotherm model was best model to explain the $\mathrm{NH}_{4}{ }^{+}$adsorption at $25^{\circ} \mathrm{C}$, indicating monolayer adsorption to a finite number of adsorption sites. The Freundlich model predicts unreasonably high ammonia uptake at low concentrations. The Fowler-Guggenheim model, which includes interaction between adsorbed molecules, gives a somewhat higher $R^{2}$ than the Langmuir isotherm. However, it fails to predict the increase of loading beyond $8 \mathrm{mg} / \mathrm{g}$ in the high concentration range. The lateral interaction parameter, $\chi=2.43$, is quite large, suggesting a strong attractive interaction between adsorbed species. Considering that ammonium is charged, it is unlikely that this is the case. We therefore concluded that the improved fit is only due to the additional degree of freedom and that the model is overparameterised.

The maximum Langmuir adsorption capacity was found to be $10.48 \mathrm{mg} / \mathrm{g}$ for $\mathrm{MT} / \mathrm{Fe}_{3} \mathrm{O}_{4} 604$ towards $\mathrm{NH}_{4}{ }^{+}$. This capacity is comparable to or better than reported for other clay-based materials (Table 3). For example, a capacity of $12.5 \mathrm{mg} / \mathrm{g}$ for $\mathrm{NH}_{4}{ }^{+}$on montmorillonite-biochar composites has been reported [58]. On the other hand, capacities of $1.54 \mathrm{mg} / \mathrm{g}$ and $1.38 \mathrm{mg} / \mathrm{g}$ have been reported for montmorillonite nano-clay and natural vermiculite, respectively [59]. Significantly higher capacity $(40.4 \mathrm{mg} / \mathrm{g})$ has been reported for $\mathrm{NH}_{4}^{+}$uptake in montmorillonite, but the liquid phase concentration was tenfold that in this study [15]. At conditions comparable to this study, however, the uptake in montmorillonite was slightly lower than here $\left(q_{\mathrm{e}}=7 \mathrm{mg} / \mathrm{g}\right.$ at $C_{\mathrm{e}}=60 \mathrm{mg} / \mathrm{L}$ ) [15].

\section{Adsorption kinetics}

The adsorption kinetics were studied in a batch adsorber using $2.5 \mathrm{~g} / \mathrm{L}$ adsorbent dosage and initial $\mathrm{NH}_{4}{ }^{+}$concentrations of $30 \mathrm{mg} / \mathrm{L}, 50 \mathrm{mg} / \mathrm{L}$, and $80 \mathrm{mg} / \mathrm{L}$. As shown in Fig. 8, the $\mathrm{NH}_{4}^{+}$uptake reaches a high level within $5 \mathrm{~min}$ for

Table 2 Parameters of the isotherm models and goodness of fit to equilibrium data

\begin{tabular}{|c|c|c|c|c|}
\hline \multirow{2}{*}{$\begin{array}{l}\text { Isotherm } \\
\text { Langmuir }\end{array}$} & \multicolumn{3}{|l|}{ Parameters } & \multirow{2}{*}{$\begin{array}{l}R^{2} \\
0.884\end{array}$} \\
\hline & $\begin{array}{l}q_{\mathrm{m}}(\mathrm{mg} / \mathrm{g}) \\
10.48\end{array}$ & $\begin{array}{l}K_{\mathrm{L}}(\mathrm{L} / \mathrm{mg}) \\
0.075\end{array}$ & & \\
\hline Freundlich & $\begin{array}{l}n \\
2.46\end{array}$ & $\begin{array}{l}K_{\mathrm{f}}\left(\mathrm{mg} / \mathrm{g} \cdot(\mathrm{L} / \mathrm{mg})^{1 / \mathrm{n}}\right) \\
1.73\end{array}$ & & 0.8731 \\
\hline \multirow[t]{2}{*}{$\begin{array}{l}\text { Fowler-Guggen- } \\
\text { heim }\end{array}$} & $q_{\mathrm{m}}(\mathrm{mg} / \mathrm{g})$ & $K_{\mathrm{FG}}(\mathrm{L} / \mathrm{g})$ & $\chi$ & 0.8935 \\
\hline & 8.24 & 0.037 & 2.43 & \\
\hline
\end{tabular}
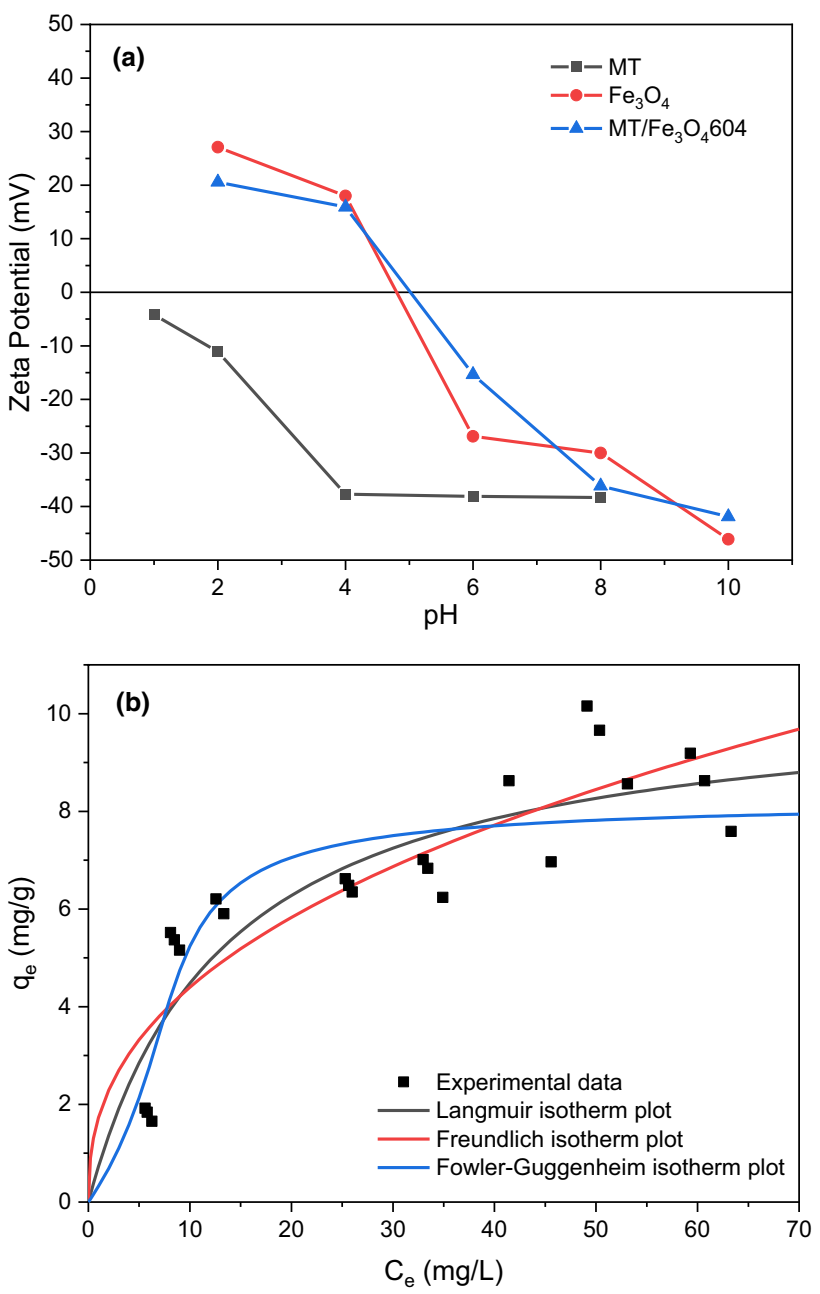

Fig. 7 a Zeta potential plots, b isotherm models

$30 \mathrm{mg} / \mathrm{L}$, and within $3 \mathrm{~min}$ for 50 and $80 \mathrm{mg} / \mathrm{L}$. The batch method is not well suited for such fast adsorption; the data are not accurate enough for discrimination between kinetic models. Nevertheless, the intra-particle diffusion model that assumes Fickian diffusion in a homogeneous medium with constant boundary conditions was applied to check if

Table 3 Comparison of adsorption capacities of similar adsorbents for $\mathrm{NH}_{4}^{+}$

\begin{tabular}{lll}
\hline Adsorbent & $\begin{array}{l}\text { Adsorption capac- } \\
\text { ity (mg/g) }\end{array}$ & References \\
\hline MT/Fe ${ }_{3} \mathrm{O}_{4}$ nanocomposite & 10.48 & Current study \\
MT nano-clay & 1.54 & {$[59]$} \\
Natural vermiculite & 1.38 & {$[59]$} \\
MT biochar composite & 12.52 & {$[58]$} \\
Natural MT & 40.4 & {$[15]$} \\
\hline
\end{tabular}




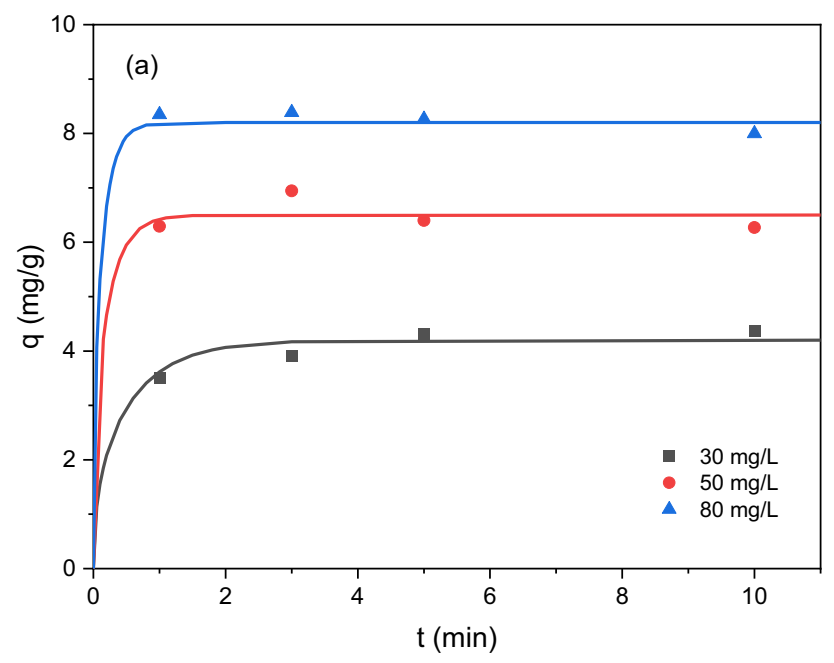

Fig. 8 Ammonium adsorption kinetics. Lines are calculated with Fickian intra-particle diffusion model (Eq. 8)

intra-particle diffusion resistance could explain the results. The loading as a function of time was calculated from Eq. (8)

$q=q_{\mathrm{eq}}\left(1-\frac{6}{\pi^{2}} \sum_{j=1}^{\infty} \frac{1}{j^{2}} \exp \left(-j^{2} \pi^{2} D^{\prime} t\right)\right)$

where $q$ and $q_{\mathrm{eq}}(\mathrm{mg} / \mathrm{g})$ are the amount adsorbed at time $\mathrm{t}$ and at equilibrium, and $D^{\prime}(1 / \mathrm{s})$ is the mass transfer parameter that includes the diffusion coefficient and the (unknown) Sauter mean diameter of the particles. The infinite series was truncated at $j=30$, which is more than sufficient as the series converges rapidly (e.g. below $1 \mathrm{e}-17$ with $j=15$ at $t=0.1 \mathrm{~min}$ ). As observed in Fig. 8, this model fits reasonably well to the data, suggesting that the intra-particle diffusion is the sole rate-limiting step [60, 61]. The mass transfer parameter $D$ ' was found to increase with increasing initial concentration (and thus loading). Values of $0.151 / \mathrm{s}$, $0.401 / \mathrm{s}$ and $0.601 / \mathrm{s}$ were obtained with initial concentrations $30 \mathrm{mg} / \mathrm{L}, 50 \mathrm{mg} / \mathrm{L}$ and $80 \mathrm{mg} / \mathrm{L}$, respectively. Since ammonium adsorption is strongly nonlinear, this suggests that diffusion may take place also in the adsorbed phase.

\section{Ammonium removal from authentic stormwater}

Application of the adsorbent to remove ammonium from an authentic stormwater was studied at laboratory scale. The operating conditions and suitable adsorbent dosing were first determined in preliminary tests.

The adsorbent dosage was varied from 1 to $5 \mathrm{~g} / \mathrm{L}$, studied using $50 \mathrm{mg} / \mathrm{L} \mathrm{NH}_{4}{ }^{+}$solution, shaking at $300 \mathrm{rpm}$ for $120 \mathrm{~min}$ at $25{ }^{\circ} \mathrm{C}$. The removal efficiency of $\mathrm{NH}_{4}{ }^{+}$ increased with increasing dosage due to the increased

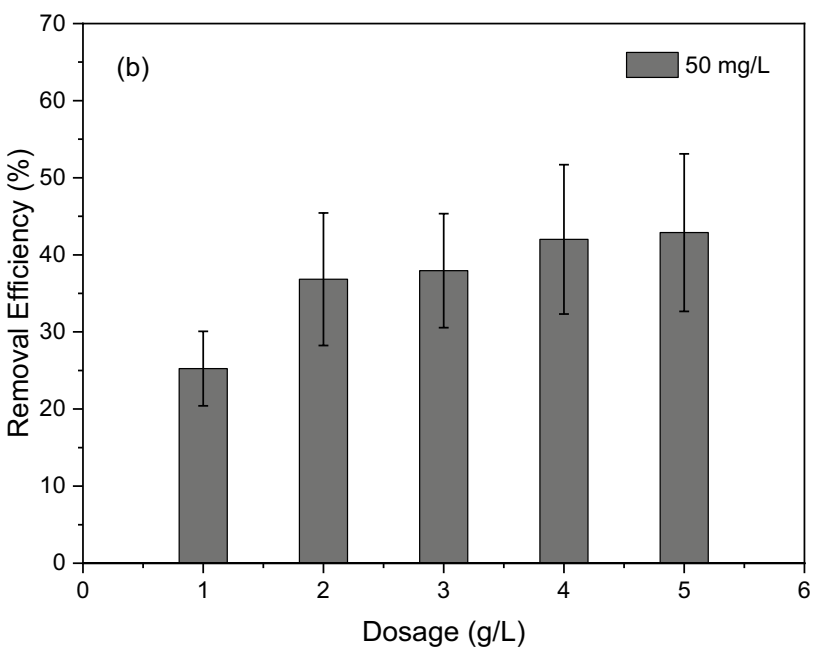

Fig. 9 Effect of adsorbent dosage on ammonium removal efficiency

active sites for $\mathrm{NH}_{4}{ }^{+}$adsorption which increased the uptake amount. As shown in Fig. 9, the removal efficiency was improved by more than 10 percentage points from 1 to $3 \mathrm{~g} / \mathrm{L}$, but less than 5 percentage points from 3 to $5 \mathrm{~g} / \mathrm{L}$. This is typical for Langmuir-type adsorption and originates from the decrease in the equilibrium concentration when the adsorbent dosage increases. Considering the cost and removal efficiency, $2.5 \mathrm{~g} / \mathrm{L}$ was selected as the optimal dosage for a single-contact adsorption process; this was used in the subsequent adsorption studies.

The adsorption efficiency of $\mathrm{MT} / \mathrm{Fe}_{3} \mathrm{O}_{4} 604$ was investigated for real stormwater collected from the landfill factory Metsäsairila Oy in Mikkeli, Finland, on August 19, 2019. The sample was filtered and used as a working solution directly for adsorption at conditions of $2.5 \mathrm{~g} / \mathrm{L}$ dosage, shaking at $300 \mathrm{rpm}$ for $1 \mathrm{~h}$ at $25^{\circ} \mathrm{C}$. The contents of the stormwater were examined by ICP-OES for $\mathrm{Na}, \mathrm{Mg}, \mathrm{Al}$, $\mathrm{K}, \mathrm{Ca}, \mathrm{Cr}, \mathrm{Mn}, \mathrm{Fe}, \mathrm{Co}, \mathrm{Ni}, \mathrm{Cu}$, and $\mathrm{Zn}$; all these elements were detected except $\mathrm{Cr}$ and $\mathrm{Co}$, which were under the detection limit.

$\mathrm{NH}_{4}{ }^{+}$removal efficiency reached $64.2 \%$ as shown in Fig. 10. Simultaneously, the concentrations of $\mathrm{Mg}, \mathrm{K}$, and $\mathrm{Ca}$ in the stormwater were reduced significantly. Heavy metals, including $\mathrm{Mn}, \mathrm{Ni}, \mathrm{Cu}$, and $\mathrm{Zn}$, were diminished to zero or nearly zero. $\mathrm{Na}$ as well as a small amount of $\mathrm{Al}$ were released by the adsorbent, which confirms the role of ion exchange mechanism. As previously discussed, Fe leaching was low since the $\mathrm{pH}$ of stormwater was 6.54. Overall, the new adsorbent recovered $\mathrm{NH}_{4}{ }^{+}$well in the presence of other metallic ions during treatment of stormwater. The additional benefit of eliminating heavy metals such as $\mathrm{Mn}$, $\mathrm{Ni}, \mathrm{Cu}$, and $\mathrm{Zn}$ to extremely low concentrations (in current case $\leq 0.1 \mathrm{mg} / \mathrm{L}$, which is lower than the detection limit of ICP-OES) is notable. 


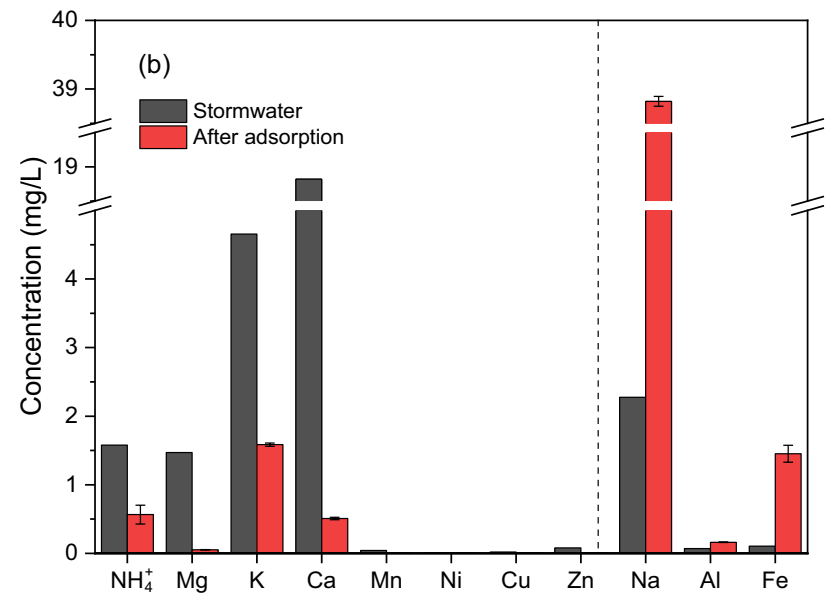

Fig. 10 Removal of ammonium and other cations from authentic stormwater using adsorbent $\mathrm{MT} / \mathrm{Fe}_{3} \mathrm{O}_{4} 604$ (solid-to-liquid phase ratio $1: 400)$

\section{Potential of reusing $\mathrm{NH}_{4}{ }^{+}$loaded adsorbents in REE recovery}

To improve the economics of adsorptive ammonium removal from stormwater, we studied the reuse of the spent (ammonium loaded) adsorbent in a secondary application. Utilising the ammonium ion-loaded adsorbents for selective recovery of valuable elements avoids the generation of chemical waste from the regeneration of adsorbents. To this end, the adsorbents were first loaded with $50 \mathrm{mg} / \mathrm{L} \mathrm{NH}_{4}{ }^{+}$solution; then, the uptake of REEs from aqueous solution was studied. The REEs used for the study include scandium (Sc), yttrium $(Y)$, and all the lanthanides except promethium (Pm). The adsorption study was conducted at conditions of $2.5 \mathrm{~g} / \mathrm{L}$ dosage, $20 \mathrm{mg} / \mathrm{L}$ working solution, shaking at $300 \mathrm{rpm}$ for $1 \mathrm{~h}$ at $25{ }^{\circ} \mathrm{C}$.

As observed in Fig. 11, the used $\mathrm{MT} / \mathrm{Fe}_{3} \mathrm{O}_{4}$ nanocomposite achieved almost $100 \%$ removal efficiency for all 16 REE ions in the single-REE containing solutions. In the mixture of all REEs, the adsorbent showed selective affinity towards $\mathrm{Sc}^{3+}$. The results indicate that the spent (ammonium loaded) $\mathrm{MT} / \mathrm{Fe}_{3} \mathrm{O}_{4}$ nanocomposite possesses the potential for REE recovery as a secondary application, especially for selective adsorption of $\mathrm{Sc}^{3+}$ among other REEs. However, regeneration of the adsorbent to recover REEs was not studied.

\section{Conclusions}

In this study, the nanocomposite of montmorilloniteanchored magnetite was synthesised and studied for the removal of ammonium in stormwater. FTIR, XRD and XPS confirmed the successful loading of $\mathrm{Fe}_{3} \mathrm{O}_{4}$ onto MT. The $\mathrm{Fe}_{3} \mathrm{O}_{4}$ enhanced the adsorption of $\mathrm{NH}_{4}{ }^{+}$and provided

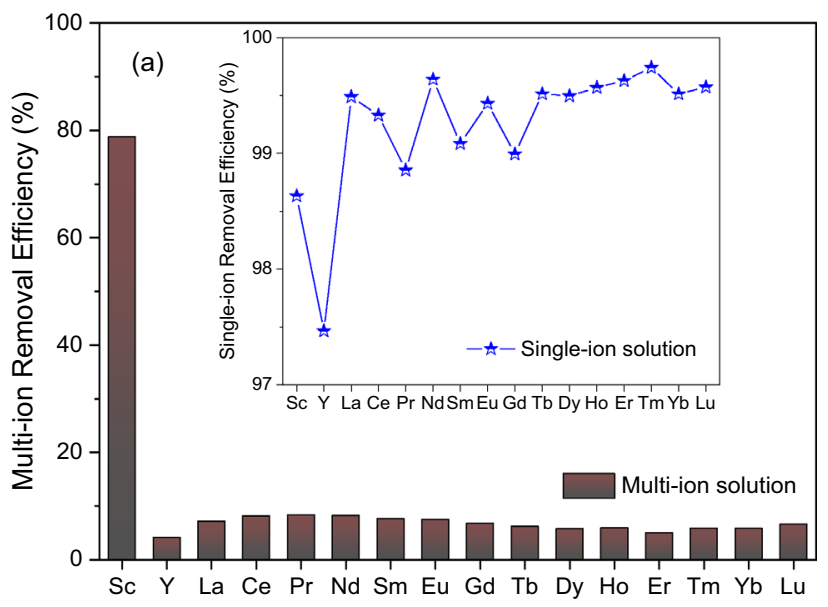

Fig. 11 Removal efficiency of spent (ammonium loaded) MT/ $\mathrm{Fe}_{3} \mathrm{O}_{4} 604$ for recovery of REEs from aqueous solution

magnetic features to MT, which accelerated the separation of the adsorbent from water. It was observed that the adsorption was influenced by dosage, contact time, initial concentration, and $\mathrm{pH}$. The adsorption behaviour of $\mathrm{NH}_{4}{ }^{+}$was well expressed by pseudo-second-order kinetics and the Temkin isotherm model. Both ion exchange and electrostatic interaction contributed to its affinity for $\mathrm{NH}_{4}{ }^{+}$. The adsorbent $\mathrm{MT} / \mathrm{Fe}_{3} \mathrm{O}_{4} 604$ was able to treat real stormwater, reducing the $\mathrm{NH}_{4}{ }^{+}$as well as heavy metal contents. Moreover, the ammonium-loaded nanocomposite possesses the potential for REE recovery as a secondary application, especially for the selective adsorption of $\mathrm{Sc}^{3+}$ among other REEs. Further study regarding the desorption of $\mathrm{Sc}^{3+}$ could be conducted to affirm and maximize the recovery potential. This study suggests that $\mathrm{MT} / \mathrm{Fe}_{3} \mathrm{O}_{4}$ nanocomposites are potential adsorbents for stormwater treatment regarding $\mathrm{NH}_{4}{ }^{+}$recovery. Furthermore, the nanocomposites could be utilised as functional material in a membrane or in polymer beads that are better suitable for large scale water treatment operations than powders $[62,63]$.

\section{Appendix A. Supplementary data}

Supplementary data associated with this article can be found in the online version.

Supplementary Information The online version contains supplementary material available at https://doi.org/10.1007/s41204-021-00151-y.

Acknowledgements This work was supported by the European Regional Development Fund (ERDF, project ID A73961) and the Academy of Finland (decision number 315051). 
Funding Open access funding provided by LUT University (previously Lappeenranta University of Technology (LUT)).

\section{Declarations}

Conflict of interest On behalf of all authors, the corresponding author states that there is no conflict of interest.

Open Access This article is licensed under a Creative Commons Attribution 4.0 International License, which permits use, sharing, adaptation, distribution and reproduction in any medium or format, as long as you give appropriate credit to the original author(s) and the source, provide a link to the Creative Commons licence, and indicate if changes were made. The images or other third party material in this article are included in the article's Creative Commons licence, unless indicated otherwise in a credit line to the material. If material is not included in the article's Creative Commons licence and your intended use is not permitted by statutory regulation or exceeds the permitted use, you will need to obtain permission directly from the copyright holder. To view a copy of this licence, visit http://creativecommons.org/licenses/by/4.0/.

\section{References}

1. Goonetilleke A, Lampard J-L (2019) Stormwater quality, pollutant sources, processes, and treatment options. In: Approaches to water sensitive urban des. Woodhead Publishing, pp 49-74. https://doi. org/10.1016/B978-0-12-812843-5.00003-4

2. Yue C, Li LY, Johnston C (2018) Exploratory study on modification of sludge-based activated carbon for nutrient removal from stormwater runoff. J Environ Manage 226:37-45. https://doi.org/ 10.1016/J.JENVMAN.2018.07.089

3. Tian J, Miller V, Chiu PC, Maresca JA, Guo M, Imhoff PT (2016) Nutrient release and ammonium sorption by poultry litter and wood biochars in stormwater treatment. Sci Total Environ 553:596-606. https://doi.org/10.1016/J.SCITOTENV.2016.02.129

4. Jones J, Chang N-B, Wanielista MP (2015) Reliability analysis of nutrient removal from stormwater runoff with green sorption media under varying influent conditions. Sci Total Environ 502:434-447. https://doi.org/10.1016/J.SCITOTENV.2014.09.016

5. Mohanty SK, Valenca R, Berger AW, Yu IKM, Xiong X, Saunders TM, Tsang DCW (2018) Plenty of room for carbon on the ground: Potential applications of biochar for stormwater treatment. Sci Total Environ 625:1644-1658. https://doi.org/10.1016/J.SCITO TENV.2018.01.037

6. Ye Y, Ngo HH, Guo W, Liu Y, Chang SW, Nguyen DD, Liang $\mathrm{H}$, Wang J (2018) A critical review on ammonium recovery from wastewater for sustainable wastewater management. Bioresour Technol 268:749-758. https://doi.org/10.1016/J.BIORTECH. 2018.07.111

7. Yan T, Ye Y, Ma H, Zhang Y, Guo W, Du B, Wei Q, Wei D, Ngo HH (2018) A critical review on membrane hybrid system for nutrient recovery from wastewater. Chem Eng J 348:143-156. https://doi.org/10.1016/J.CEJ.2018.04.166

8. Srivastava V, Iftekhar S, Wang Z, Babu I, Sillanpää M (2018) Synthesis and application of biocompatible nontoxic nanoparticles for reclamation of $\mathrm{Ce} 3+$ from synthetic wastewater: toxicity assessment, kinetic, isotherm and thermodynamic study. J Rare Earths 36:994-1006. https://doi.org/10.1016/J.JRE.2018.03.005

9. Ramasamy DL, Khan S, Repo E, Sillanpää M (2017) Synthesis of mesoporous and microporous amine and non-amine functionalized silica gels for the application of rare earth elements
(REE) recovery from the waste water-understanding the role of $\mathrm{pH}$, temperature, calcination and mechanism in Light REE and Heavy REE separation. Chem Eng J 322:56-65. https://doi.org/ 10.1016/J.CEJ.2017.03.152

10. Ramasamy DL, Repo E, Srivastava V, Sillanpää M (2017) Chemically immobilized and physically adsorbed PAN/acetylacetone modified mesoporous silica for the recovery of rare earth elements from the waste water-comparative and optimization study. Water Res 114:264-276. https://doi.org/10.1016/J.WATRES.2017.02. 045

11. Srivastava V, Sillanpää M (2017) Synthesis of malachite@ clay nanocomposite for rapid scavenging of cationic and anionic dyes from synthetic wastewater. J Environ Sci 51:97-110. https://doi. org/10.1016/J.JES.2016.08.011

12. Jacobs JD, Koerner H, Heinz H, Farmer BL, Mirau P, Garrett PH, Vaia RA (2006) Dynamics of alkyl ammonium intercalants within organically modified montmorillonite: dielectric relaxation and ionic conductivity. J Phys Chem B 110:20143-20157. https://doi.org/10.1021/jp0619311

13. Peng C, Zhong Y, Min F (2018) Adsorption of alkylamine cations on montmorillonite (001) surface: a density functional theory study. Appl Clay Sci 152:249-258. https://doi.org/10. 1016/J.CLAY.2017.11.021

14. Bhattacharyya KG, Sen Gupta S (2006) Kaolinite, montmorillonite, and their modified derivatives as adsorbents for removal of $\mathrm{Cu}$ (II) from aqueous solution. Sep Purif Technol 50:388-397. https://doi.org/10.1016/J.SEPPUR.2005.12.014

15. Alshameri A, Zhu R, Ma L, Tao Q (2018) Adsorption of ammonium by different natural clay minerals: characterization, kinetics and adsorption isotherms. Appl Clay Sci 159:83-93. https:// doi.org/10.1016/J.CLAY.2017.11.007

16. Nabi G, Qurat-ul-Aain NR, Khalid MB, Tahir M, Rafique M, Rizwan S, Hussain T, Iqbal AM (2018) A Review on novel ecofriendly green approach to synthesis tio2 nanoparticles using different extracts. J Inorg Organomet Polym Mater 28:15521564. https://doi.org/10.1007/s10904-018-0812-0

17. Nassar NN (2012) Iron oxide nanoadsorbents for removal of various pollutants from wastewater: an overview. In: Application of adsorbents for water pollution control. Bentham Science Publishers, Sharjah, pp 81-118

18. Liu F, Zhou K, Chen Q, Wang A, Chen W (2018) Preparation of magnetic ferrite by optimizing the synthetic $\mathrm{pH}$ and its application for the removal of Cd(II) from Cd-NH3-H2O system. J Mol Liq 264:215-222. https://doi.org/10.1016/J.MOLLIQ.2018.05. 038

19. Liu F, Zhou K, Chen Q, Wang A, Chen W (2019) Application of magnetic ferrite nanoparticles for removal of $\mathrm{Cu}$ (II) from copperammonia wastewater. J Alloys Compd 773:140-149. https://doi. org/10.1016/j.jallcom.2018.09.240

20. Zheng X, Dou J, Yuan J, Qin W, Hong X, Ding A (2017) Removal of Cs+ from water and soil by ammonium-pillared montmorillonite/Fe3O4 composite. J Environ Sci 56:12-24. https://doi.org/ 10.1016/j.jes.2016.08.019

21. Fadillah G, Yudha SP, Sagadevan S, Fatimah I, Muraza O (2020) Magnetic iron oxide/clay nanocomposites for adsorption and catalytic oxidation in water treatment applications. Open Chem 18:1148-1166. https://doi.org/10.1515/chem-2020-0159

22. Tahir MB, Iqbal T, Kiran H, Hasan A (2019) Insighting role of reduced graphene oxide in $\mathrm{BiVO} 4$ nanoparticles for improved photocatalytic hydrogen evolution and dyes degradation. Int J Energy Res 43:2410-2417. https://doi.org/10.1002/er.4443

23. Rafique M, Sadaf I, Tahir MB, Rafique MS, Nabi G, Iqbal T, Sughra K (2019) Novel and facile synthesis of silver nanoparticles using Albizia procera leaf extract for dye degradation and antibacterial applications. Mater Sci Eng C 99:1313-1324. https:// doi.org/10.1016/j.msec.2019.02.059 
24. Castro-Muñoz R (2020) The role of new inorganic materials in composite membranes for water disinfection. Membranes (Basel). https://doi.org/10.3390/membranes10050101

25. Rafique M, Nawaz H, Shahid Rafique M, Bilal Tahir M, Nabi G, Khalid NR (2019) Material and method selection for efficient solid oxide fuel cell anode: Recent advancements and reviews. Int J Energy Res 43:2423-2446. https://doi.org/10.1002/er.4210

26. Abboud M, Youssef S, Podlecki J, Habchi R, Germanos G, Foucaran A (2015) Superparamagnetic Fe3O4 nanoparticles, synthesis and surface modification. Mater Sci Semicond Process 39:641-648. https://doi.org/10.1016/J.MSSP.2015.05.035

27. Gong P, Yu J, Sun H, Hong J, Zhao S, Xu D, Yao S (2006) Preparation and characterization of $\mathrm{OH}$-functionalized magnetic nanogels under UV irradiation. J Appl Polym Sci 101:1283-1290. https://doi.org/10.1002/app.23250

28. Afsheen S, Tahir MB, Iqbal T, Liaqat A, Abrar M (2018) Green synthesis and characterization of novel iron particles by using different extracts. J Alloys Compd 732:935-944. https://doi.org/ 10.1016/j.jallcom.2017.10.137

29. Yadav GD, Bokade VV (1996) Novelties of heteropoly acid supported on clay: etherification of phenethyl alcohol with alkanols. Appl Catal A Gen 147:299-323. https://doi.org/10.1016/S0926860X(96)00206-2

30. K. Y Nandiwale, P. S Niphadkar, V. V Bokade, Synthesis of Oxygenated Fuel Additives via Acetylation of Bio-Glycerol over H2SO4 Modified Montmorillonite K10 Catalyst, Prog. Petrochemical Sci. 1 (2018). https://doi.org/10.31031/PPS.2018.01. 000501

31. Bhandari S, Kasana V (2018) Fe3+-montmorillonite K10 as an efficient, green and reusable heterogeneous catalyst for synthesis of mannich type reaction under solvent-free condition. Int Res J Pure Appl Chem 16:1-11. https://doi.org/10.9734/IRJPAC/2018/ 41983

32. Marsh A, Heath A, Patureau P, Evernden M, Walker P (2018) Alkali activation behaviour of un-calcined montmorillonite and illite clay minerals. Appl Clay Sci 166:250-261. https://doi.org/ 10.1016/J.CLAY.2018.09.011

33. Sadegh H, Shahryari-ghoshekandi R, Kazemi M (2014) Study in synthesis and characterization of carbon nanotubes decorated by magnetic iron oxide nanoparticles. Int Nano Lett 4:129-135. https://doi.org/10.1007/s40089-014-0128-1

34. Mascolo M, Pei Y, Ring T, Mascolo MC, Pei Y, Ring TA (2013) Room temperature Co-precipitation synthesis of magnetite nanoparticles in a large ph window with different bases. Mater. (Basel) 6:5549-5567. https://doi.org/10.3390/ma6125549

35. Tahir MB, Rafique M, Isa Khan M, Majid A, Nazar F, Sagir M, Gilani S, Farooq M, Ahmed A (2018) Enhanced photocatalytic hydrogen energy production of g-C3N4-WO3 composites under visible light irradiation. Int J Energy Res 42:4667-4673. https:// doi.org/10.1002/er.4208

36. Lu H, Wang J, Li F, Huang X, Tian B, Hao H (2018) Highly efficient and reusable montmorillonite/Fe3O4/humic acid nanocomposites for simultaneous removal of $\mathrm{Cr}(\mathrm{VI})$ and aniline. Nanomaterials 8:537. https://doi.org/10.3390/nano8070537

37. Lu W, Shen Y, Xie A, Zhang W (2010) Green synthesis and characterization of superparamagnetic $\mathrm{Fe} 3 \mathrm{O} 4$ nanoparticles. J Magn Magn Mater 322:1828-1833. https://doi.org/10.1016/J.JMMM. 2009.12.035

38. Jubb AM, Allen HC (2010) Vibrational spectroscopic characterization of hematite, maghemite, and magnetite thin films produced by vapor deposition. ACS Appl Mater Interfaces 2:2804-2812. https://doi.org/10.1021/am1004943

39. Rani S, Varma GD (2015) Superparamagnetism and metamagnetic transition in $\mathrm{Fe} 3 \mathrm{O} 4$ nanoparticles synthesized via co-precipitation method at different pH. Phys B Condens Matter 472:66-77. https://doi.org/10.1016/j.physb.2015.05.016
40. Gu Z, Gao M, Luo Z, Lu L, Ye Y, Liu Y (2014) Bis-pyridinium dibromides modified organo-bentonite for the removal of aniline from wastewater: a positive role of $\pi-\pi$ polar interaction. Appl Surf Sci 290:107-115. https://doi.org/10.1016/J.APSUSC.2013. 11.008

41. Kozak M, Domka L (2004) Adsorption of the quaternary ammonium salts on montmorillonite. J Phys Chem Solids 65:441-445. https://doi.org/10.1016/J.JPCS.2003.09.015

42. Thommes M, Kaneko K, Neimark AV, Olivier JP, RodriguezReinoso F, Rouquerol J, Sing KSW (2015) Physisorption of gases, with special reference to the evaluation of surface area and pore size distribution (IUPAC technical report). Pure Appl Chem 87:1051-1069. https://doi.org/10.1515/pac-2014-1117

43. Ursino C, Castro-Muñoz R, Drioli E, Gzara L, Albeirutty MH, Figoli A (2018) Progress of nanocomposite membranes for water treatment. Membranes (Basel). https://doi.org/10.3390/membr anes 8020018

44. Castro-Muñoz R, Gontarek E, Figoli A (2019) Membranes for toxic- and heavy-metal removal. In: Current Trends and Future Developments on (Bio-) Membranes. Elsevier Inc., pp 125-149. https://doi.org/10.1016/B978-0-12-816778-6.00007-2

45. Zare K, Sadegh H, Shahryari-ghoshekandi R, Asif M, Tyagi I, Agarwal S, Gupta VK (2016) Equilibrium and kinetic study of ammonium ion adsorption by $\mathrm{Fe} 3 \mathrm{O} 4$ nanoparticles from aqueous solutions. J Mol Liq 213:345-350. https://doi.org/10.1016/J. MOLLIQ.2015.08.045

46. Copcia V, Hristodor C, Luchian C, Bilba N, Sandu I (2010) Ammonium nitrogen removal from aqueous solution by natural clay. Rev Chim (Bucharest) 61:1192-1196

47. Liu H, Peng S, Shu L, Chen T, Bao T, Frost RL (2013) Effect of $\mathrm{Fe} 3 \mathrm{O} 4$ addition on removal of ammonium by zeolite $\mathrm{NaA}$. J Colloid Interface Sci 390:204-210. https://doi.org/10.1016/J. JCIS.2012.09.010

48. Cowan CT, White D (1958) The mechanism of exchange reactions occurring between sodium montmorillonite and various n-primary aliphatic amine salts. Trans Faraday Soc 54:691-697. https://doi.org/10.1039/TF9585400691

49. Rožić M, Cerjan-Stefanović Š, Kurajica S, Vančina V, Hodžić E (2000) Ammoniacal nitrogen removal from water by treatment with clays and zeolites. Water Res 34:3675-3681. https://doi. org/10.1016/S0043-1354(00)00113-5

50. Wang J, Zheng S, Shao Y, Liu J, Xu Z, Zhu D (2010) Aminofunctionalized $\mathrm{Fe} 3 \mathrm{O} 4 @ \mathrm{SiO} 2$ core-shell magnetic nanomaterial as a novel adsorbent for aqueous heavy metals removal. J Colloid Interface Sci 349:293-299. https://doi.org/10.1016/J.JCIS. 2010.05.010

51. Cheng Y, Huang T, Shi X, Wen G, Sun Y (2017) Removal of ammonium ion from water by Na-rich birnessite: performance and mechanisms. J Environ Sci 57:402-410. https://doi.org/10. 1016/J.JES.2016.11.015

52. Langmuir I (1918) The adsorption of gases on plane surfaces of glass, mica and platinum. J Am Chem Soc 40:1361-1403. https://doi.org/10.1021/ja02242a004

53. Freundlich HMF (1906) Over the adsorption in solution. J Phys Chem 57:1100-1107

54. Saadi R, Saadi Z, Fazaeli R, Fard NE (2015) Monolayer and multilayer adsorption isotherm models for sorption from aqueous media. Korean J Chem Eng 32:787-799. https://doi.org/10. 1007/s11814-015-0053-7

55. Sips R (1948) Combined form of Langmuir and Freundlich equations. J Chem Phys 16:490-495

56. Srivastava V, Sharma YC, Sillanpää M (2015) Application of nano-magnesso ferrite (n-MgFe2O4) for the removal of $\mathrm{Co} 2+$ ions from synthetic wastewater: kinetic, equilibrium and thermodynamic studies. Appl Surf Sci 338:42-54. https://doi.org/ 10.1016/J.APSUSC.2015.02.072 
57. Srivastava V, Weng CH, Singh VK, Sharma YC (2011) Adsorption of nickel ions from aqueous solutions by nano alumina: kinetic, mass transfer, and equilibrium studies. J Chem Eng Data 56:1414-1422. https://doi.org/10.1021/je101152b

58. Chen L, Chen XL, Zhou CH, Yang HM, Ji SF, Tong DS, Zhong ZK, Yu WH, Chu MQ (2017) Environmental-friendly montmorillonite-biochar composites: Facile production and tunable adsorption-release of ammonium and phosphate. J Clean Prod 156:648-659. https://doi.org/10.1016/J.JCLEPRO.2017.04.050

59. Mazloomi F, Jalali M (2017) Adsorption of ammonium from simulated wastewater by montmorillonite nanoclay and natural vermiculite: experimental study and simulation. Environ Monit Assess 189:415. https://doi.org/10.1007/s10661-017-6080-6

60. Qiu H, Lv L, Pan B, Zhang Q, Zhang W, Zhang Q (2009) Critical review in adsorption kinetic models. J Zhejiang Univ A 10:716-724. https://doi.org/10.1631/jzus.A0820524

61. Iftekhar S, Srivastava V, Casas A, Sillanpää M (2018) Synthesis of novel GA-g-PAM/SiO2 nanocomposite for the recovery of rare earth elements (REE) ions from aqueous solution. J Clean Prod 170:251-259. https://doi.org/10.1016/J.JCLEPRO.2017.09.166

62. Castro-Muñoz R, González-Melgoza LL, García-Depraect O (2021) Ongoing progress on novel nanocomposite membranes for the separation of heavy metals from contaminated water. Chemosphere 270:129421. https://doi.org/10.1016/j.chemosphere.2020. 129421

63. Castro-Muñoz R (2020) The strategy of nanomaterials in polymeric membranes for water treatment: nanocomposite membranes. Tecnol y Ciencias Del Agua. 11: 410-436. https://doi. org/10.24850/j-tyca-2020-01-11

Publisher's Note Springer Nature remains neutral with regard to jurisdictional claims in published maps and institutional affiliations.

\section{Authors and Affiliations}

\section{Jianzhi Song ${ }^{1} \cdot$ Varsha Srivastava $^{1} \cdot$ Tomas Kohout $^{2} \cdot$ Mika Sillanpäää $^{3,4,5,6,7,8} \cdot$ Tuomo Sainio $^{1}$ (i)}

1 Department of Separation Science, School of Engineering Science, LUT University, Sammonkatu 12, 50130 Mikkeli, Finland

2 Department of Geosciences and Geography, University of Helsinki, Helsinki, Finland

3 Department of Chemical Engineering, School of Mining, Metallurgy and Chemical Engineering, University of Johannesburg, P. O. Box 17011, Doornfontein 2028, South Africa

4 School of Chemical and Metallurgical Engineering, University of the Witwatersrand, Johannesburg 2050, South Africa
5 Chemistry Department, College of Science, King Saud University, Riyadh 11451, Saudi Arabia

6 Department of Biological and Chemical Engineering, Aarhus University, Nørrebrogade 44, 8000 Aarhus C, Denmark

7 Faculty of Science and Technology, School of Applied Physics, University Kebangsaan Malaysia, 43600 Bangi, Selangor, Malaysia

8 International Research Centre of Nanotechnology for Himalayan Sustainability (IRCNHS), Shoolini University, Solan 173212, Himachal Pradesh, India 